ANL/EAIS/TM--30

DE91 001085

ANL/EAIS/TM-30

\title{
U.S. Fossil Fuel Technologies for Thailand
}

by W.A. Buehring, G.E. Dials, * J.L. Gillette, C.B. Szpunar, and P.A. Traczyk

International Coal and Environmental Studies, and Systems Analysis Sections, Environmental Assessrnent and Information Sciences Division, Argonne National Laboratory, 9700 South Cass Avenue, Argonne, Illinois 60439

July 1988 (printed in October 1990)

Work sponsored by United States Department of Energy, Assistant Secretary for Fossil Energy, Office of Fossil Energy

"Dials is now affiliated with Massey Coal Services, Inc. Daniels, W. Va. WHSTER 


\section{CONTENTS}

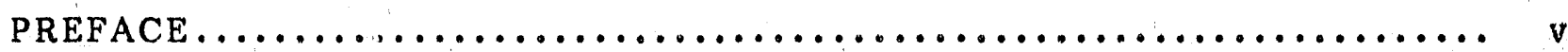

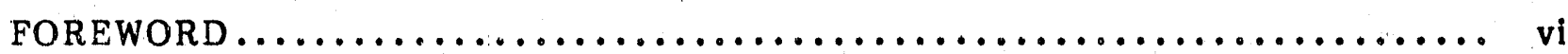

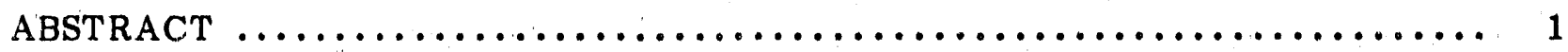

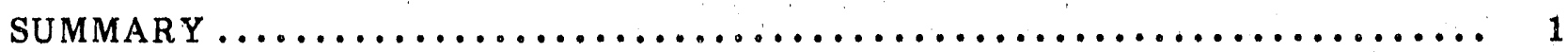

1 ThaILAND PROFILE $\ldots \ldots \ldots \ldots \ldots \ldots \ldots \ldots \ldots \ldots \ldots \ldots \ldots \ldots \ldots \ldots \ldots \ldots$

1.1 Human and Political Profile $\ldots \ldots \ldots \ldots \ldots \ldots \ldots \ldots \ldots \ldots \ldots \ldots \ldots \ldots$

1.2 Energy Overview ...................................... 4

1.2.1 Electric Utility Situation $\ldots \ldots \ldots \ldots \ldots \ldots \ldots \ldots \ldots \ldots \ldots \ldots \ldots \ldots$

1.2 .2 Industrial Energy Sector ........................ 10

1.2.3 Natural Energy Resources .......................... 1 1

1.2.4 Energy Transportation Infrastructure $\ldots \ldots \ldots \ldots \ldots \ldots \ldots \ldots \ldots \ldots 14$

1.3 Financial, Economic, and Trade Issues ..................... 16

1.3.1 Impact of Financial, Economic, and Trade Issues ........... 16

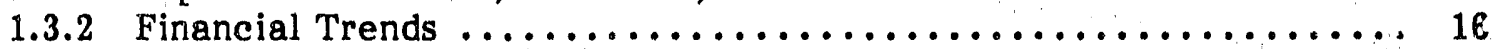

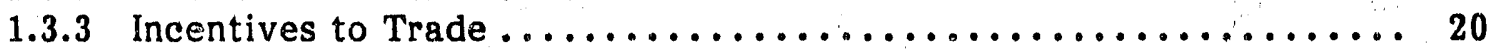

1.3.4 Financing, Insurance, and Investment Options .............. 22

1.3.5 National Trade Objectives .......................... 22

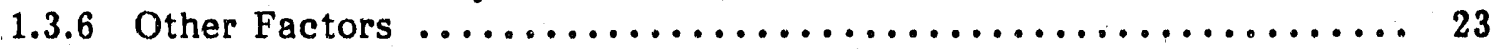

2 OPPORTUNITIES FOR ENERGY PROJECTS IN THAILAND ............ 25

2.1 Electric Utility Sector ............................ 25

2.1.1 Atmospheric Fluidized-Bed-Combustor Application for EGAT ..... 26

2.1.2 Metropolitant Electricity Authority Refurbishing ........... 27

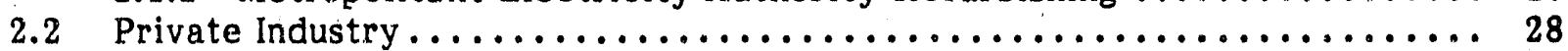

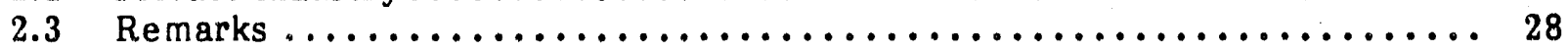

EIBLIOGRAPHY $\ldots \ldots \ldots \ldots \ldots \ldots \ldots \ldots \ldots \ldots \ldots \ldots \ldots \ldots \ldots \ldots \ldots \ldots \ldots$

APPENDIX A: Screening of Candidate Countries $\ldots \ldots \ldots \ldots \ldots \ldots \ldots \ldots \ldots$

APPENDIX B: America's Clean Coal Commitment ................ 37

APPENDIX C: Major U.S. Companies Doing Business in Thailand .......... 51

\section{TABLES}

S.1 Opporturities for Energy Projects in Thailand $\ldots \ldots \ldots \ldots \ldots \ldots \ldots \ldots \ldots \ldots$

1 EGAT-Owned Generation Capacity, $1987 \ldots \ldots \ldots \ldots \ldots \ldots \ldots \ldots \ldots \ldots$

2 EG.AT Capacity, $1988-2001 \ldots \ldots \ldots \ldots \ldots \ldots \ldots \ldots \ldots \ldots \ldots \ldots \ldots \ldots$

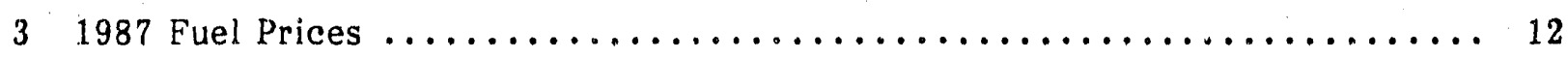


TABLES (Cont'd)

4 Thailand: Key Economic Indicators $\ldots \ldots \ldots \ldots \ldots \ldots \ldots \ldots \ldots \ldots \ldots, 17$

5 Application for Investments $\ldots \ldots \ldots \ldots \ldots \ldots \ldots \ldots \ldots \ldots \ldots \ldots \ldots, 20$

6 Electricity Cost by Option $\ldots \ldots \ldots \ldots \ldots \ldots \ldots \ldots \ldots \ldots \ldots \ldots \ldots \ldots, 26$

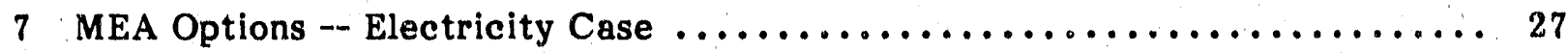

A.1 Countries Meeting Screening Criteria $\ldots \ldots \ldots \ldots \ldots \ldots \ldots \ldots \ldots \ldots \ldots \ldots, 34$

\section{FIGURES}

1 Thai Labor Force $\ldots \ldots \ldots \ldots \ldots \ldots \ldots \ldots \ldots \ldots \ldots \ldots \ldots \ldots \ldots, 3$

2 Thailand's Exports versus Imports $\ldots \ldots \ldots \ldots \ldots \ldots \ldots \ldots \ldots \ldots \ldots \ldots, 18$

3 Thailand's 1986 Exports and Imports by Country $\ldots \ldots \ldots \ldots \ldots \ldots \ldots \ldots \ldots .19$

A.1 Summary of Screening Process $\ldots \ldots \ldots \ldots \ldots \ldots \ldots \ldots \ldots \ldots \ldots \ldots \ldots, 33$ 


\title{
PREFACE
}

"... Technology can play a major role in improving competitiveness in a global market. ...DOE, as the advocate for energy in the Federal government, has the responsibility to provide leadership with other elements of government in developing a policy environment that is conducive to making U.S. energy technology more competitive in world energy markets."

\author{
Abstract, $R \& D$ Initiatives for \\ Energy Competitiveness \\ Energy Research Advisory Board, \\ March 1988
}

"The Federal government and the coal industry should pursue a broad, integrated and coordinated strategy to promote the use of coal in developing countries for power generation in the interest of national security and expanded coal exports."

Improving International

Competitiveness of U.S. Coals

and Coal Technologies

National Coal Council,

June 1987

"The Clean Coal Technology Program of the United States offers an opportunity to provide a marketing advantage to coal exporters by linking the sales of U.S. coals with clean coal technologies that have been commercially proven in domestic markets. Combining the coal and the technology in a package offering proven and effective environmental and economic benefits may be especially attractive to countries which are just beginning to develop coal-based energy systems."

Report of the Federal Coal Export Commission

U.S. Department of Commerce, May 1988 


\section{FOREWORD}

The U.S. Department of Energy (DOE) is working with other federal agencies and with industry on a broad and flexible range of initiatives to improve the U.S. trade balance and energy security through increased exports of coal and coal technology.

The wise and productive use of energy and energy technology is a key factor in every country for the development and maintenance of economic well being and national security. Energy helps to meet the personal needs of people in their homes and fuels the industries that employ them. Energy is a significant component of agricultural and manufactured goods for export. These exports in turn help earn the hard currency needed to import critical skills and products from abroad that are essential to assist in the continuing process of national development.

The availability, cost, and effectiveness of energy deployment directly affects national productivity and competitiveness.

The United States is blessed with a wide range of energy resources and has continuously been a world leader in the development of energy technologies. In particular, the large and varied U.S. coal resource and its high level of coal utilization in the world give the United States unparalleled scope and capability in this fuel and technology field. This leadership is being continued and strengthened through a multibillion dollar presidential initiative to develop and demonstrate a suite of advanced clean coal technologies (CCTs). This ccil imitment to improved coal utilization and a quality environment is unmatched by any chiner nation.

As Secretary of Energy John S. Herrington noted (1)* in early 1987:

America is determined to become the "world's showcase" of new clean coal technology. In addition to accelerating our environmental progress here at home, new clean coal options can help strengthen the common bonds of cooperation with our international neighbors and provide new articles of trade.

Discussions between U.S. industry and federal agencies have suggested that the government might be helpful in collecting and disseminating information regarding development of markets for coal and coal technologies. In response, DOE, Office of Fossil Energy, has been screening world energy markets to identify opportunities for using the technological innovations we are advancing domestically as the basis for encouraging other countries to look to U.S. coal and coal technologies to meet their energy needs in the future.

The initial focus of this information collection activity has been on three selected developing countries: Costa Rica, the Dominican Republic, and Thailand.

*Throughout this report, numbers in parentheses are keyed to the alphabetized bibliography, which contains cited references and other relevant documents. 
Clearly, newly industrialized countries, as well as other developing countries, represent potentially favorable market areas as well. Similarly, while the technological driving force is the suite of emerging CCTs for electric power generation and commercial/ industrial use, it is recognized that the currently established suite of U.S. coal technologies may also support market opportunities abroad as precursors to relationships that can continue with $\mathrm{CCT}$ products.

The various Fossil Energy initiatives have actively sought the input and participation of other interested federal agencies. Indeed, the U.S. Agency for International Development helped to sponsor the early studies that identified specific countries for more intensive follow-on activity (Appendix A). The results of these initial efforts are presented in this report and its companion documents for review, use, and comment by U.S. industry. Because the objective of these efforts is to assist U.S. industry in increasing exports and improving the U.S. trade balance, constructive industry review and comment will contribute greatly to the selection and emphasis of subsequent phases of the Fossil Energy initiatives.

International trade is founded on the concept of mutual benefit. The energy fuels and technology skills possessed by the United States and its industry of fer increased development capabilities and improved economic well being for international purchasers of these capabilities. Their increased economic stability and participation in the international marketplace aids world stability and security. In turn, U.S. security and other important national objectives are enhanced. The success of these initiatives must ultimately be reflected, however, in the quality and vigor of U.S. private sector actions and in the active cooperation and support of energy users in potential host countries.

This work, which was completed in July 1988, was presented at a public meeting on U.S. fossil fuel technologies for developing countries, held on July 21, 1988, in Washington, D.C. Although some of the country profile data are now dated, the opportunities for energy projects appear to remain valid. This information is therefore being published in the public interest. 


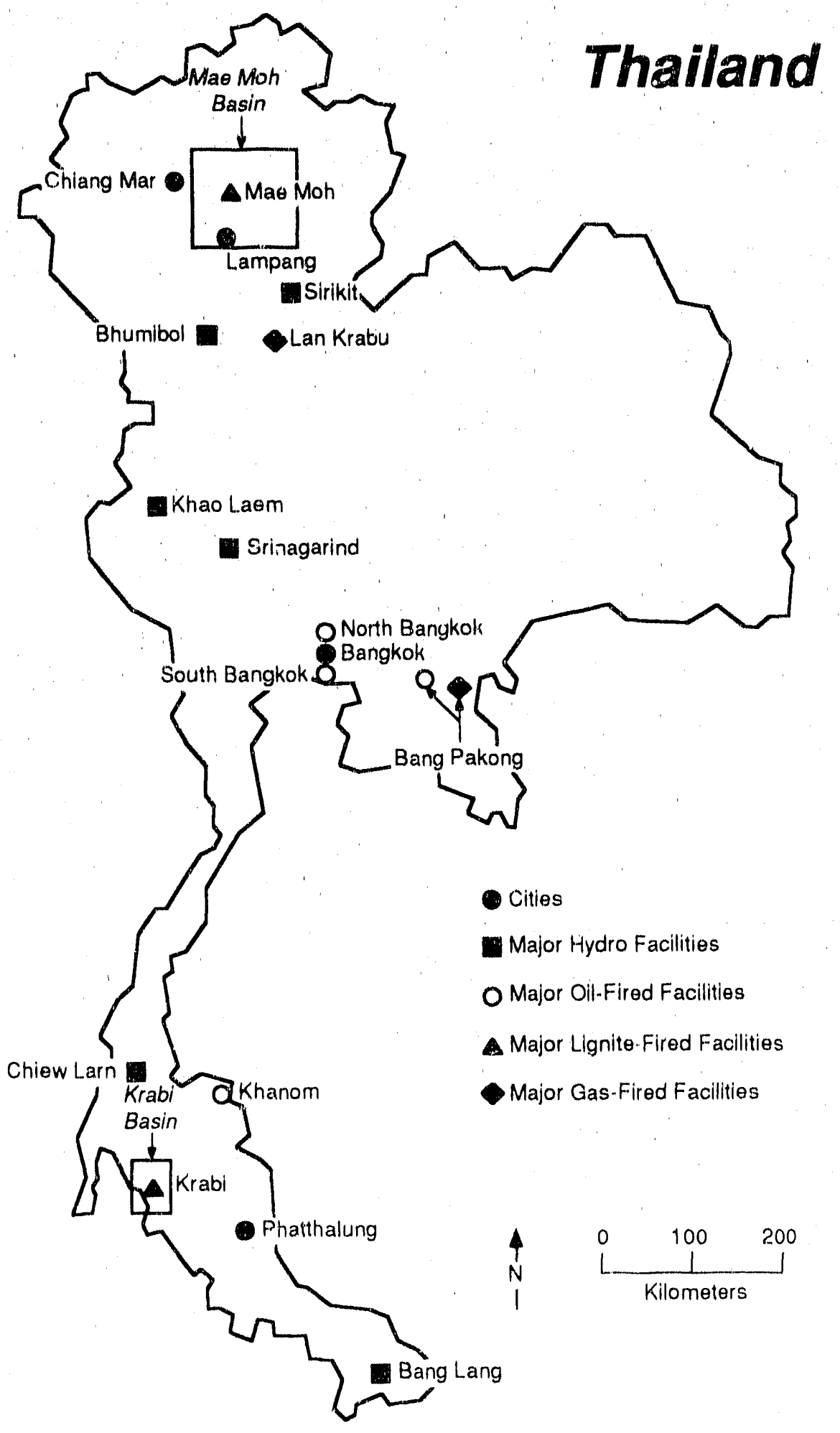




\title{
U.S. FOSSIL FUEL TECHNOLOGIES FOR THAILAND
}

\author{
by
}

\author{
W.A. Bueluring, G.E. Dials, J.L. Glllette, \\ C.B. Szpunar, and P.A. Traczyk
}

\begin{abstract}
The U.S. Department of Energy has been encouraging other countries to consider U.S. coal and coal technologies in meeting their future energy needs. Thalland is one of three developing countries cetermined to be a potentially favorable market for such exports. This report briefly profiles Thailand with respect to population, employment, energy infrastructure and policies, as well as financial, economic, and trade issues. Thailand is shif ting from a traditionally agrarian economy to one based more strongly on light manufacturing and will therefore require increased energy resources that are reliable and flexible in responding to anticipated growth. Thailand has extensive lignite deposits that could fuel a variety of coal-based technologies. Atmospheric fluidized-bed combustors could utllize this resource and still permit Thailand to meet emission standards for sulfur dioxide. This option also lends itself to small-scale applications suitable for private-sector power generation. Slagging combustors and coal-water mixtures also appear to have potential. Both new construction and refurbishment of existing plants are planned.
\end{abstract}

\section{SUMMARY}

Electricity demand in Thalland has been growing rapidly for several years and is expected to continue to do so into the next century. Thalland intends to maximize the development of indigenous coal reserves, and it exhibits an environmental awareness that is somewhat atypical for a developing country. Thailand's high economic growth rate and favorable investment policies make it attractive for both domestic and foreign investors. Thus, significant trade opportunities for U.S. businesses exist in Thailand's electric and industrial power markets.

This report characterizes Thailand's energy situation; discusses the financial, economic, and trade issues; and summarizes energy project opportunities in Thailand.

Thailand has several types of natural energy resources, including lignite. Additional discoveries of high-quality lignite will provide a relatively inexpensive source of fuel starting in the mid-1990s. However, for the near term, Thalland will likely depend on imported oil and perhaps coal to supplement domestic production. The 1987 
peak electrical demand was 4,734 $\mathrm{MW}$, whlch represented a 13 percent increase from 1986. The Electricity Generating Authority of Thailand (EGAT) has an ambitious investment program for new capacity to meet this rapidly growing demand. As of September 1987, the EGAT-owned generation capacity was 6,926 MW; ir addition, it purchases power from Laos and Malaysia. To meet increasing demand with the use of lignite, EGAT has two 300-MW lignite-fired units at Mae Moh and plans for adding seven 300-MW units by 1995. Two 75-MW units are planned for construction in southern Thailand.

Thailand's pro-business stance, conservative fiscal and monetary policies, abundant natural resources, skilled labor, and growing infrastructure all help to create a generally good investment climate. Thalland had a steady economic performance in 1987 as the country moved closer to the threshold of a newly industrialized country. One of the major nbjectives of the country's Sixth National Economic and Social Development Plan for $1987-1991$ (12) is to raise Thalland's level of development.

Conditions in Thailand led to several U.S. advanced fossil fuel technologies being selected for consideration in conjunction with potential project opportunities. These technologies are the atmospheric fluidized bed combustor, coal-water mixtures, and the slagging combustor. These technologies could play a major role in the capacity expansion and/or conversion opportunities listed in Table S.1. The total value of such projects could approximate U.S. $\$ 3.3$ billion.

TABLE S.1 Opportunities for Energy Projects in Thailand

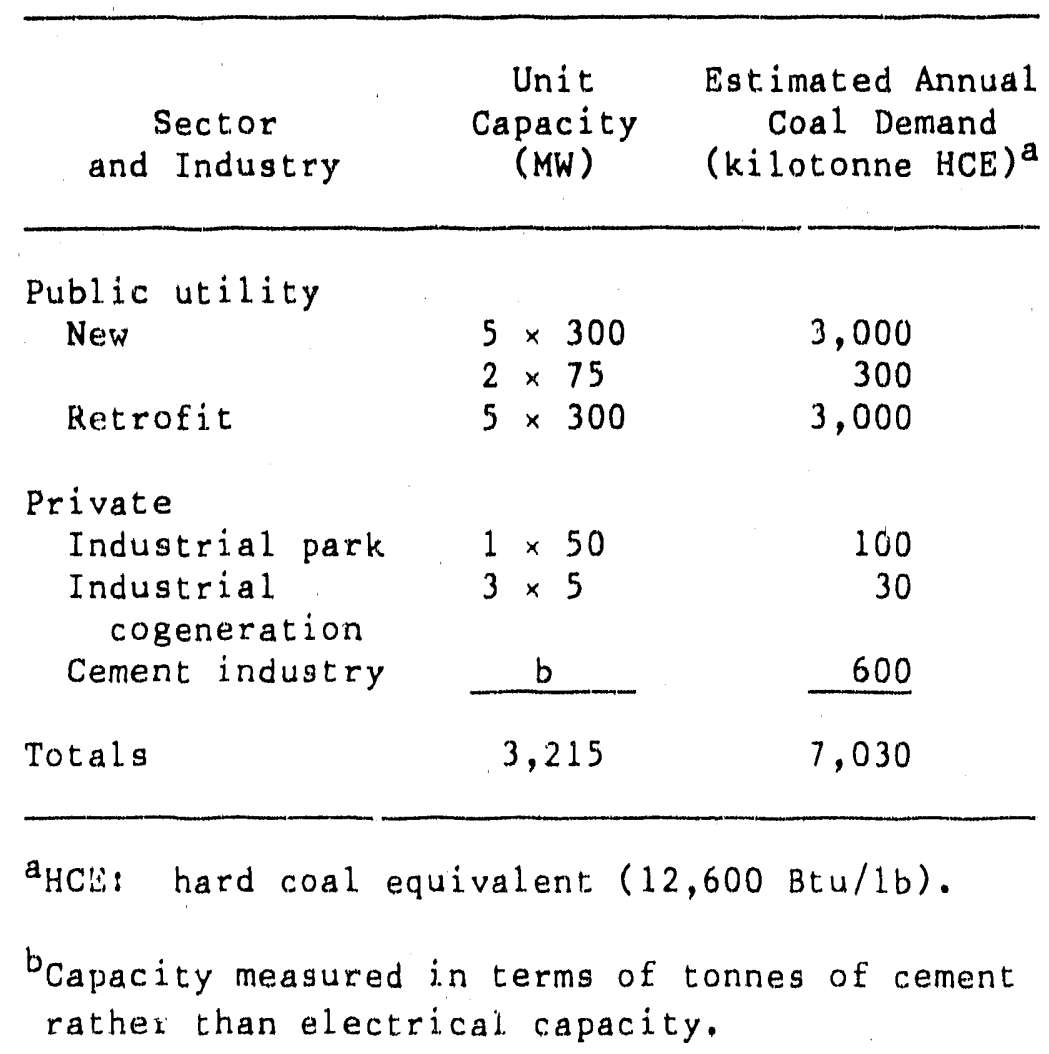




\section{THAILAND PROFILE}

\subsection{HUMAN AND POLITICAL PROFILE}

The population of Thailand is estimated at 55 million, of which approximately 8.3 million live in the greater Bangkok area (6 million in central Bangkok, the capital). The population of the greater Bangkok area is expected to increase to 9.3 million by 1991, when it will rank among the 15 largest cities in the world. In its attempts to relieve congestion in Bangkok, the government has engaged in a major campaign to promote development outside this urban area. The eastern seaboard and other new economic zones are targeted for large industries.

The Sixth National Economic and Social Development Plan (1987-1991) has a target of 3.9 million new jobs to alleviate both rural and urban unemployment. Currently, only about 7 percent of the work force is employed in industry. Estimates for technical and related workers in manufacturing, electricity, g'as, and water are 23,000 in 1986; potential scientists and engineers number 20,000, while potential technicians number 47,000. Overall, Thalland has a well-educated and capable work force for the industrial development that lies ahead (Figure 1).

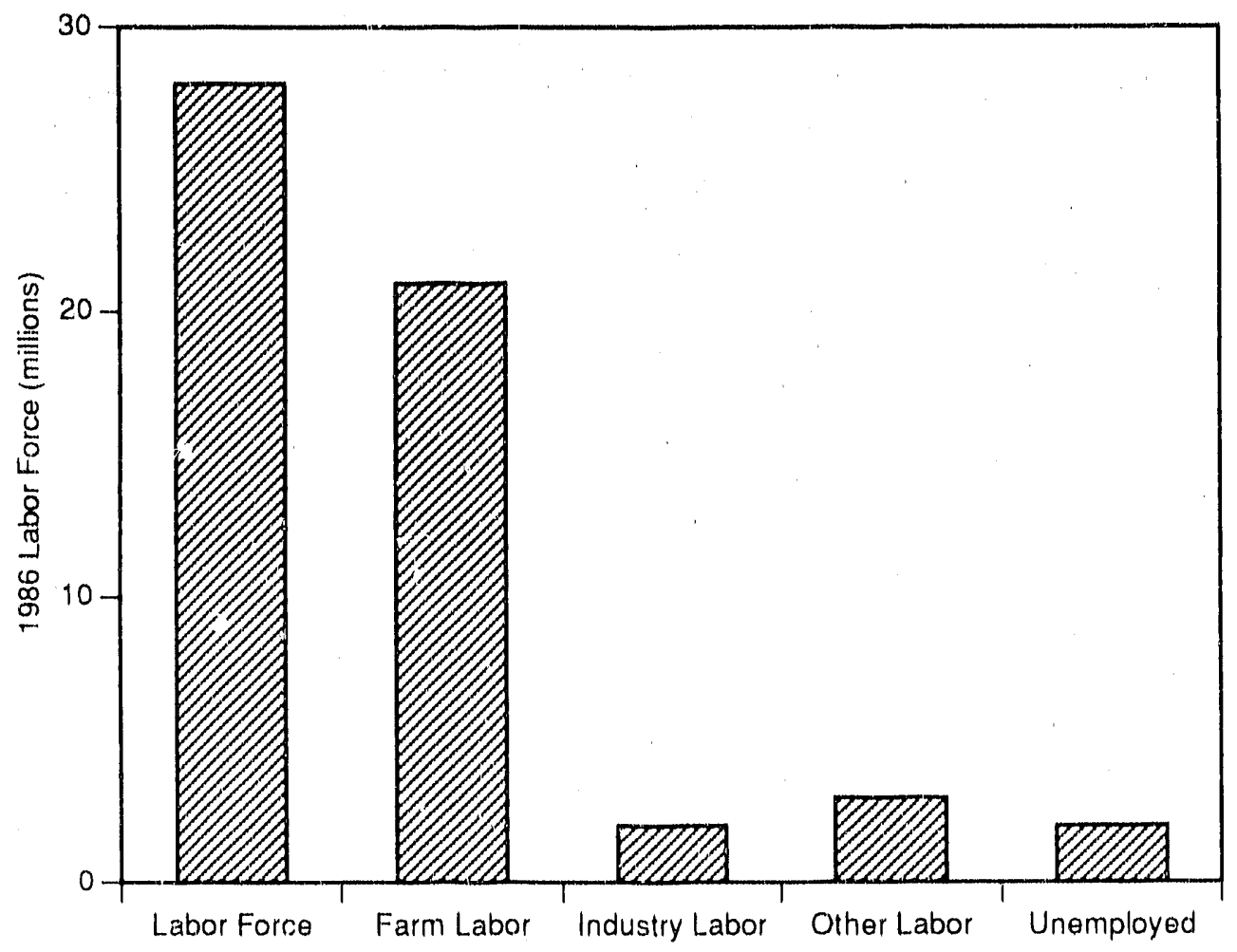

PIGURE 1 Thai Labor Force (Source: Ref. 5) 
Thailand has been a constitutional monarchy since 1932. The king has considerable influence and has played an important role in maintaining the current stability. There are 73 provinces in Thalland, each of which is governed by a provincial governor, appointed by the minister of interior.

The present constituticn, which took effect in 1978, provides for a parliament of 225 appointed senators and 301 elected members of a house of representatives. At the national level, executive power is administered and legislation is proposed by the cabinet, on which all the ministries are represented. The cabinet is chaired by the prime minister, whose post was established in 1933. The first 25 years of constitutional government saw the prime minister's power gradually increase. Since 1958, prime ministers have played the dominant role in running the country. A major change in power occurred in 1974 with a violent coup d'etat. The current prime minister has been in office since 1978 and has provided a relatively stable political environment that has supported economic growth.

A number of government agencies are principal actors the energy sector. These include the National Energy Administration (NEA), the Petroleum Authority of Thailand, the Electricity Generating Authority of Thailand (EGAT), the Ministry of Industry, and, only recently, the National Environrient Board. The NEA has attempted to provide overall gidance for the energy sector, but the other organizations operate independently and have not officially followed NEA's lead. Cooperation among these agencies occurs on a personal level to a limited extent.

\subsection{ENERGY OVERVIEW}

Responsibility for policy formulation, energy services, and regulation is dispersed among several aggencies in Thailand. The agency responsible for energy generation is EGAT. The Thal government encourages EGAT to use natural gas and has provided a subsidy to keep the utility from switching to imported oil for economic and national security reasons. Thailand intends to maximize the development of indigenous coal reserves and increase the development of alternative energy resources, including microhydro, biogas, oll shale, and geothermal. The government recognizes the need for increased reliable energy generation with the expected growth in the manufacturing, industrial, and service sectors of the economy.

Thailand has several natural energy resources, including natural gas, lignite, hydropower, and some oil. Among the renewable resources are forest products, rubber tree waste, sugar cane processing residue (bagasse), and sugar cane field waste. The electrical sector, like the industrial sector, has experienced and is expected to continue to have very high growth rates. Therefore, additional generating capacity is needed. EGAT has an ambitious investment program for new capacity, but demand is exceeding estimates. The investment program will not be adequate. The electric power sector currently accounts for more than 60 parcent of the government investment in public enterprises.

New discoverles of high-quality lignite will provide a relatively inexpensive source of fuel starting in the mid 1990s. This development will help considerably in 
meeting demand, particularly in southern Thailand. For the near term, and for some time in to the future, Thailand will depend heavily on imported oll to meet domestic energy needs. In 1980, the country depended on imported ofl for more than 75 percent of its total energy requirements. Since then, dependence on imported oil has been reduced by about one-third. A rapidly growing domestic industrial demand for power will promote greater use of conservation methods and cogeneration. EGAT is releasing its tight grip on private power sales to encourage private investment in power generation. The EGAT expansion plans emphasize increased reliance on lignite for power generation.

Increased use of lignite will have environmental consequences. In the absence of pollution regulations, new investment in lignite combustion equipment could ignore the need for pollution control. However, the Thai government is expected to issue pollution regulations in the next few years. Thus, potential opportunities for utilization of clean coal technologies (CCTs) would be enhanced. Project opportunities have been identifled in both the electric and industrial sectors.

\subsubsection{Electric Utility Situation}

\subsubsection{Electricity Demand}

Electricity demand in Thailand has been rapidly growing for several years and is expected to continue to grow into the next century. The 1987 peak demand was 4,734 MW, which represented a 13.2 percent increase from 1986 (11). This large increase is the result of the rapid economic recovery that has recently taken place in Thailand. In 1986, about 46 percent of the electricity produced was used in the industrial sector, about 27 percent in commercial facilities, and 26 percent in the residential sector, with the remaining 1 percent consumed in street lighting, agriculture, and other activities (3). For Thailand's population of 55 million, per capita electricity consumption in 1986 was about $420 \mathrm{kWh}$. The projected growth rate for peak demand is 8.2 percent/year through 1991, when it is expected to reach $6,481 \mathrm{MW}$. The growth rate is expected to decrease slightly to about 7.3 percent/year in the $1992-1996$ period and to 5.1 percent/year in the 1997-2001 time frame. The anticipated peak demands for 1996 and 2001 are 9,202 MW and $11,821 \mathrm{MW}$, respectively (11)

About 62 percent of the households in Thailand are electrified (3). This figure represents approximately 6 million households. However, electricity usage is not uniform throughout the country. About one million of the electrified homes are in the greater Bangkok area; they represent about 89 percent of the population in this area. About 40 percent of the electricity used in the residential sector is consumed in these one million households. About half of the electrified homes outside the Bangkok area qualify for what is called a lifeline tariff because they use less than $35 \mathrm{kWh} / \mathrm{month}$. About 54 percent of the ronsumption in the commercial and industrial sectors also occurs in the greater Bangkok area. 


\subsubsection{Geographic Pattern of Powrs Consumption}

Thailand is divided into four major regions. The Central Region (Region 1) covers central Thailand and includes Bangkok. Approximately one-third of the total population lives in this region, with 65 percent of these people living in electrified homes. This region consumes about 78 percent of the electrical energy, with about 50 percent being used in the greater Bangkok area and two adjoining provinces.

In the Northeast (Region 2), which also has about one-thirid of the tutal population of the country, 56 percent of the population lives in electrified households. This region accourts for only 8 percent of the total national electricity consumption.

Southern Thailand (Region 3) has about 12 percent of the population, with 6 percent of the total electricity consumption. Approximately 48 percent of the households are electrified.

In the North (Region 4), the population is about 20 percent of the national total. Roughly 55 percent of the households are electrified, with the total electricity use at 8 percent of the national total.

The growth rates and the benefits associated with increased electrical use are regionally dependent. The average ann'lal demand growth in the 1987-200: period is estimated to be approximately 6 percent in the greater B\&ngkok area and 8 percent in the rest of the country. The annual growth in electricity sales is expected to average 7 percent in the Bangkok area and 8 percent in the other areas.

\subsubsection{Generating Capacity}

The responsibility for power generation has been given to EGAT, which was formed in May 1969. EGAT also is responsible for production and sale of indigenous lignite resources and for power transmission. The Metropolitan Electricity Authority (MEA) is responsible for distributing electricity within the greater Bangkok area and Nonthaburi and Samut Prakan provinces. The Provincial Electricity Authority (PEA) distributes the power in the rest of the country. EGAT also has 10 direct customers to whom it sells power. These customers include cement companies, oil refineries, and military installations. Alsout $765 \mathrm{MW}$ of privately owned capacity in Thailand is used to meet in-house demand.

As of September 1987, the EGAT-owned generation capacity in Thailand was $6,926 \mathrm{MW}$ (Table 1). In addition, EGAT purchases surplus power from the Nam Ngum dam in Laos and has a power exchange agreement with the facility at Sadao in Malaysia.

\subsubsection{Distribution}

The standard transmission voltages are $500,230,115$, and $69 \mathrm{kV}$ at $50 \mathrm{~Hz}$. The four regions of thie EGAT system are connected via 230- or $115-\mathrm{kV}$ transmission lines. As the generation system is expanded, the transmission system is upgraded or expanded in a consistent fashion. The Central-Southern Tie Line forms a major link between central 
and southern Thailand, and a second such link is being considered. The connection between southern Thailand and northern Malaysia has been in operation since February 1981. A second connection is under consiceration that would enabie power transfers of 100,200 , or $300 \mathrm{MW}$ between the two countries.

Transmission and distribution losses are estimated at 10 or 11 percent of the dispatched output, but have been as low as 8 to 9 percent for some years $(3,11)$.

\subsubsection{Natural Gas and Oil}

In 1987, the gas-fired steam and combined cycle units made up approximately 46 percent of the capacity and produced about 48 percent of the electricity. Heavy oil units accounted for only 5 percent of the capacity but produced about 11 percent of the electricity. This difference appeared even though the price of natural gas was lower than the price of oil. As an explanation, gas production records indicate that EGAT was limited to an average of 354 million cubic feet per day. With this constraint, the electricity production from these units was limited to about $13,690 \mathrm{GWh}$, or an average capacity factor of about 49 percent. The lignite units operate at their maximum capacity factor, and the hydro units are predominantly used in the peaking mode; therefore, the heavy oil units are used to produce the power that would have come from the gas units if there had been sufficient gas supply. The production of natural gas is expected to increase in the next few years, but these will continue to be a constraint on the use of natural gas for most years in the planning period. A second 75-MW barge-mounted plant burning oil or gas is currently under construction at Khanom in southern Thailand and will be operational in December 1988.

\subsubsection{Hydropower}

As noted above, the hydroelectric capacity in Thailand is used predominantly as peaking capacity. Thus, even though the hydro capacity is about 32 percent of the total, it produced only about 16 percent of the energy, for an average capacity factor of about 27 percent. Even the largest hydro units (200 to $400 \mathrm{MW}$ ) have capacity factors of only 30 percent or less.

\subsubsection{Lignite}

EGAT has undertaken an aggressive expansion plan in order to meet future demand. Two 300-MW lignite-fueled units are under construction at Mae Moh (in the 
North) and are expected to be on-line in Juiy 1989 and December 1990. Many other construction and renovation projects have been identified by EGAT as being needed by 2001 to meet expected demand. Approximately 7,536 $\mathrm{MW}$ of additional capacity (beyond the 675 MW currently under construction) has been planned to meet this demand and to account for the $467 \mathrm{MW}$ of anticipated retirements. These projects are in various stages of planning.

\subsubsection{Expansion Plans}

There are significant differences in electricity demand among the geographic regions of Thailand. Generating capacity and the anticipated need for additional capacity also differ.

Central. In the Central Region (Bangkok and 26 surrounding provinces), the base load demand is met with oil- and gas-fired steam piants at South Bangkok and Bang Pakong, along with the gas-fired combined cycle units at Bang Pakong. Current plans for this region call for expansion of the combined cycle capacity by $600 \mathrm{MW}$ by January 1992. An additional $180 \mathrm{MW}$ of hydro capacity will be operational at Srinagarind in April 1992 and will be used as peaking capacity. A 550-W gas/oil unit at Bang Pakong will be operational in December 1992 and a similar unit in November 1995. Four hydro plants of $145 \mathrm{MW}$ each are planned for Upper Quae Yai in late 1996 and early 1997. Five 600-MW coal-fired units to be added between 1997 and 2001 complete the expansion plan for the region.

A total of $5,460 \mathrm{MW}$ of new capacity is projected for this region. This figure represents almost two-thirds of the total capacity additions projected for Thailand in the 1987-2001 time frame. In addition to this new capacity, there are plans to do a considerable amount of renovation at both the North and South Bangkok oil/gas-fired plants. These plants represent more than 1,500 MW of capacity.

Northeast. The base load demand in the Northeast (16 provinces) is met by importing power from the Central Region and purchasing power from the Nam Ngum dam in Laos. Twin 105-MW gas-fired combined cycle units are under construction at Nam Phong and are expected to be operational in November 1989 and January 1991. Four 34-MW hydro units at Pak Mun are planned for operation in December 1993. Thus, total planned additions in the Northeast are $346 \mathrm{MW}$.

South. This region (14 provinces) includes the Krabi Basin, where lignite reserves have been found and are now being used to only a limited extent. Base-load demand in this region is currently met by the twin $20-\mathrm{MW}$ lignite-fueled units at Krabi (a third $20-\mathrm{MW}$ unit has already been retired, and the twin units are scheduled for retirement in 1990), the 75-MW barge-mounted, oil-fired unit at Khanom, the $30-\mathrm{MW}$ oil-fired plant at Surat Thani, and the $115-\mathrm{kV}$ Central-Southern Tie Line. The South is also connected to Malaysia via a 132-kV tie line to help meet peak dema.ıd. 
This region is expected to experience a rapid increase in demand. It is therefore anticipated that an additional $1,000 \mathrm{MW}$ of generation capacity will be needed by 1997 . The most recent EGAT plans show only a 75-MW lignite plant at Krabi to begin operation in November 1992 and another 75-MW lignite plant at Sin Pun to begin operation in October 1995 (11). Thus, there appears to be a great need for additional capacity tu be planned and constructed in this region. The new lignite discovery at Saba Yoi has given EGAT a major new source of fuel for power generation in the South. EGAT has expressed an interest in implementing a major new power project there at the same time it prepares the infrastructure for mining operations. The earliest date for possible power generation from Saba Yoi is the mid-1990s. A proposed feasibility study for Saba Yoi will be completed in 1991. Upgrading the Central-Southern Tie Line is another option that EGAT will consider if demand in the South exceeds the generating capacity.

North. The Mae Moh lignite reserves are in the North, which also includes the upper part of Central Thailand. This lignite is burned in power piants that provide the bulk of the base-load power. Expansion is based on further utilization of the lignite, with seven 300-MW units planned to begin operation between now and April 1995.

Planning Criteria. Table 2 presents a detailed summary of the EGAT expansion plan through the year 2001. EGAT uses three basic planning criteria when considering expansion of its generating system. The first deals with the loss of the largest units in

TABLE 2 EGAT Capacity, 1988-2001 (MW)

\begin{tabular}{lrrrrrrrr}
\hline Year & Hydro & $\begin{array}{r}\text { Oil/ } \\
\text { Steam }\end{array}$ & $\begin{array}{c}\text { Gas/ } \\
\text { Steam }\end{array}$ & Lignite & Coal & $\begin{array}{c}\text { Comb. } \\
\text { Cycle }\end{array}$ & Peaking & Total \\
\hline 1988 & 2,250 & 342 & 2,400 & 865 & 0 & 772 & 297 & 8,926 \\
1989 & 2,250 & 418 & 2,400 & 1,165 & 0 & 772 & 297 & 7,301 \\
1990 & 2,250 & 418 & 2,400 & 1,165 & 0 & 772 & 437 & 7,441 \\
1991 & 2,250 & 418 & 2,400 & 1,425 & 0 & 982 & 465 & 7,939 \\
1992 & 2,430 & 418 & 2,400 & 1,725 & 0 & 1,582 & 265 & 8,819 \\
1993 & 2,430 & 418 & 2,950 & 1,800 & 0 & 1,582 & 145 & 9,324 \\
1994 & 2,646 & 418 & 2,950 & 2,400 & 0 & 1,582 & 100 & 10,095 \\
1995 & 2,646 & 418 & 2,950 & 3,000 & 0 & 1,582 & 100 & 10,695 \\
1996 & 2,646 & 418 & 3,500 & 3,075 & 0 & 1,582 & 100 & 11,320 \\
1997 & 3,226 & 418 & 3,500 & 3,075 & 0 & 1,582 & 100 & 11,900 \\
1998 & 3,226 & 388 & 4,100 & 3,075 & 0 & 1,582 & 100 & 12,470 \\
1799 & 3,226 & 388 & 4,100 & 3,075 & 1,200 & 1,582 & 100 & 13,670 \\
2000 & 3,226 & 388 & 4,100 & 3,075 & 1,800 & 1,582 & 100 & 14,270 \\
2001 & 3,226 & 388 & 3,900 & 3,075 & 2,400 & 1,582 & 100 & 14,670 \\
\hline
\end{tabular}

Source: Ref. 11 
the system. This criterion defines system firm generating capacity as being equal to the total available capacity of hydro and thermal plants minus the available capacity of the first and second largest units in the system.

A second criterion is that of the reserve margin. The reserve margin is equal to the difference between the total available capacity and the peak load, divided by the peak load. History has shown that the EGAT system requires a reserve margin of about 25 percent to ensure that the loss of load probability (the third criterion) will not exceed 1 day/year. However, recent government policy and the limitations of foreign currency borrowing have dictated that the reserve margin be reduced to 15 to 20 percent for planning purposes.

The third and final criterion used in system planning is loss of load probability (LOLP). This parameter considers the outage rates of each unit in the system and combines them into a measure of overall system reliability. In the past, EGAT has used an LOLP of less than 1 day/year as a planning criterion. As noted above, however, new restrictions on reserve margin have limited EGAT's ability to maintain this LOLP level. The most recent EGAT expansion plan will have annual LOLPs in the range of 0.3 to 2.5 days/year.

\subsubsection{Industrial Energy Sector}

\subsubsection{Major Industries}

Thailand is on the verge of being classified as a newly industrialized country, along with Hong Kong, South Korea, and Taiwan. Manufacturing has been a leading source of growth in the Thai economy. Throughout the $1960 \mathrm{~s}$ and early 1970s, the government influenced the structure of the manufacturing sector primarily through policies designed to encourage import substitution. Thailand now has a very sophisticated industrial capability that includes iron and steel products and electronic equipment as well as assembly plants for motor vehicles, engines, refrigeration and air conditioning equipment, and agricultural machinery, along with cement, textiles, chemicals, and transport equipment.

With the development of natural gas fields in the Gulf of Siam, the Thai government er.barked on a U.S. $\$ 5$ billion industrial development plan for petrochemical and other heavy and light industries along the eastern seaboard. An economic downturn in the mid-1980s caused some of those projects to be shelved. The existing industrial centers are located in or around Bangkok, but attempts are being intensified to attract manufacturers to regional areas outside Bangkok.

One of the largest industrial energy consumers is the cement industry (15). Siam Cement, the largest private industrial company in the country, resisted using indigenous lignite because the high ash content made it not worth the high transport cost. However, by mixing the lignite with steam coal imported from the People's Republic of China, an 
adequate Btu level is obtained and the problem of ash sufficiently mitigated. The cement industry is now importing 600,000 tonnes of steam coal per year to mix with indigenous lignite.

Except for agricultural processing plants that use biomass (agricultural waste) as a source of fuel, most industries currently depend on fuel oil for meeting their energy needs. However, lignite represents a less expensive and more reliable source of fuel. While few companies are decommissioning their current oil-fired systems to install lignite-fired equipment, new systems are more frequently designed for lignite.

\subsubsection{Cogeneration}

About $400 \mathrm{MW}$ of cogeneration capacity is currently used to supply the in-house needs of Thai industry (10). No power generated from this capacity is sold to EGAT, elther because the in-house needs are just met or because there is no agreed price or policy for such transactions. Because the majority of this capacity is fueled with agricultural wastes (particularly bagasse from the sugar industry), the supply from these sources is seasonal. With the recent interest in lignite-fired boilers, a new opportunity exists for cogeneration.

In some cases, such as in industrial parks, economies of scale can be achieved if a private power and steam generating facility can serve more than one user. To date, there has been little interest in planning such a facility because private power was not permitted to be sold. EGAT holds the monopoly and appeared to want to keep that status. The Thai government is now encouraging the devolution of state authority to the private sector. EGAT has acknowledged its inability to make the necessary investment for new power generation. It is viewing favorably the purchase of power from a private power project sponsored by the Agency for International Development (AID), with sugar cane trash as fuel. EGAT is looking to the private sector to invest in new generating capacity. Industrial estates such as Bangpoo are prime areas for lignite-fired cogeneration facilities.

\subsubsection{Fuel Prices}

The 1987 prices for fuel delivered to EGAT are given in Table 3. Projections to 2001 indicate annual increases of about 4 percent for fuel oil, 2 percent for imported coal, 3 percent for natural gas, and less than 0.5 percent for lignite.

\subsubsection{Natural Energy Resources}

The more important energy resources are of ishore and onshore natural gas, lignite, hydropower, and oil/condensates. Renewables represent an additional resource for power generation. 


\subsubsection{Natural Gas}

Natural gas resources are found both offshore and onshore. Major natural gas iteserves have been discovered in the Gulf of Thailand. The proven and recoverable reserves are estimated at 3.4 trillion cubic feet (15). Currently, the Erawan and Platong fields, which together total 1.53 trillion cubic feet of proven reserves, are supplying about 400 million cubic feet/day. Of this, about 300 million cubic feet/day are being used by EGAT for gas-fired steam units, gas-fired combustion turbines, and gas-fired combined cycle units. Most of this capacity is located near Bangkok.
TABLE 31987 Fuel Prices

\begin{tabular}{|c|c|}
\hline Fuel & U.S. \$/million Btu \\
\hline $\begin{array}{l}\text { Fuel oil } \\
\text { Imported coal } \\
\text { Natural gas } \\
\text { Indigenous } \\
\quad \text { lignite }\end{array}$ & $\begin{array}{l}2.74 \\
1.60 \text { ( } \$ 44 / \text { tonne) } \\
2.44 \\
1.58 \text { ( } \$ 18.40 / \text { tonne) }\end{array}$ \\
\hline
\end{tabular}

Source: Ref, 11

Natural gas has also been discovered at Nam Phong in northeastern Thailand and at Lan Krabu in northwestern Thailand. The proven reserve of 0.28 trillion cubic feet at Nam Phong will be used first in twin 105-MW gas-fired combined cycle units currently under construction. EGAT plans to develop a total of $600 \mathrm{MW}$ of combined cycle power generation for Nam Phong. The Lan Krabu site is supplying about 17 inillion cubic feet/day for $120 \mathrm{MW}$ of power from gas turbines.

EGAT is by far the largest user of naturel gas in Thailand, with feedstock being the second largest use $(11,15)$. Historically, gas use by EGAT has been in Excess of 90 percent of the total natural gas use in Thailand. However, production levels are currently limited and the siuppliers have put a high price on their product. The Thai government wants EGAT to use natural gas and has given it a subsidy to keep it from switching to oil. Production from the gas flields is projected to increase from the 429 million cubic feet/day in 1987 to about 1,100 million cubic feet/day by 1995 and then remain nearly constant through 2001. A large increase in feedstock consumption is projected for 1990, when usage will go from 70 to 157 million cubic feet/day. It is then expected to grow to level of 227 million cubic feet/day in 1994 and remain steady through 2001. Industrial use is expected to grow from the $5 \mathrm{million}$ cubic feet/day used in 1987 to about 110 million cubic feet/day in 2001 .

The net result of the increased production and the increased usage in the feedstock and industrial sectors is that EGAT is projected to have an adequate gas supply only until the mid- to late 1990s. Planned consumption levels appe $r$ to be changing as a result of increased use of inexpensive domestic lignite. Many indusiries are reluctant to use natural gas berause of the current high price.

\subsubsection{Lignite}

In 1986, approximately 5.5 million tonnes of lignite were mined in Thailand (15). EGAT used 4.7 million tonnes in the production of electricity and the cement industry 
used about 0.5 million tonnes. This latter use is rapidly growing, as shown by comparing current use to the 4,000 tonnes used in 1980 .

Lignite reserves of 614 million tonnes have been proven at the Mae Moh mines in the Northern Region. It is estimated that these reserves are capable of supporting approximately 3,000 MW of capacity throughout the lifetime of the power plants. About $825 \mathrm{MW}$ of capacity is currently associated with this resource, and there are plans to add seven 300-MW units between now and April 1995.

At present, about 5.5 million tonnes of lignite are mined annually from Mae Moh. The energy content is about $5,200 \mathrm{Btu} / \mathrm{lb}$, with an ash content of about 30 percent. Siam Cement is using Mae Moh lignite, combining it with imported steam coal from China and Australia to increase the energy content.

The Northern Region has a second source of lignite in Chiang Mai province at Wiang Haeng. Total reserves there are estimated at 107 million tonnes with about 25 million recoverable.

Lignite reserves also exist in the South. The Krabi Basin has total reserves of 120.7 million tonnes, of which about 20 million are recoverable. The quality of the lignite is quite variable, but the average energy content appears to be about $4,150 \mathrm{Btu} / \mathrm{lb}$. It contains about 23 to 28 percent molsture, 26 percent ash (with only a small fraction of the ash in the form of calcium oxide), and 3 to 4 percent sulfur. Two $20 . \mathrm{MW}$ units are using this lignite and are expected to use less than one million tonnes before their retirement in 1990 . Thus, approximately 13 million tonnes remain avallable for future generation facilities. This fuel should be sufficiert for a $75-\mathrm{MW}$ power plant to operate at base load for 25 to 30 years. The current plan calls for operation of such a plant beginning in November 1992.

Other lignite reserves have been found at Sin Pun, about $60 \mathrm{~km}$ northeast of the Krabi Basin. This lignite is believed to be of better quality than the Krabi lignite but to have slightly more sulfur. The proven reserves are currently given as more than 10 million tonnes. This quantity should also be enough to fuel a $75-\mathrm{MW}$ plant for its lifetime. The current plan calls for this facility to begin operation in October 1995 .

A major new discrovery of lignite reserves was made in Saba Yoi in 1987. At least 50 million tonnes of recoverable reserves have been located. Additional exploration in the area is expected to result in the discovery of many times this initial amount. An important feature of this new discovery is the high quality of the lignite. The energy content is at least $6,500 \mathrm{Btu} / \mathrm{lb}$ and may average as high as 7,600 Btu/lb or more. Also, the sulfur content is less than that of the other deposits in Thailand.

\subsubsection{Hydroelectric}

The hydropower potential is estimated at $9,300 \mathrm{MW}$, excluding the two international rivers (the Mekong and the Salween); EGAT has already harnessed about 2,250 MW of this. Hydroelectric capacity currently represents about one-third of the installed power generating capacity, and there are plans for almost $1,000 \mathrm{MW}$ of 
additional hydro capacity within the next 10 years. An additional $900 \mathrm{MW}$ are under study.

The NEA is emphasizing small-scale hydiopower, for which the potential is estimated at $3,000 \mathrm{MW}$ over 100 sites. Most of the existing and planned hydro capacity is found in three of the four regions, the exception being the Southern Region. As noted earlier, however, the hydro capacity is used in the peaking mode, with an average capacity factor of less than 30 percent.

For the long term, the Mekong River and its tributaries represent a major hydropower resource. About $19,000 \mathrm{MW}$ can be obtained from seven sites along the river. The tributaries in Laos alone can produce an estimated 18,000 MW. However, exploitation of these resources will require more cooperation among the riparian countries of Kampuchea, Laos, Thailand, and Vietnam than is currently possible.

\subsubsection{Oil/Condensate}

Thailand also has some oil reserves, with approximately 43 million bbl in proven leserves and another 335 million bbl classified as probable $(8,15)$. The production rate has been quite low, however, with the result that in 1986 about 87 percent of the crude oil refined in Thailand was imported. In northern Thailand, a small reserve produces about 1,000 bbl/day. The condensate contributions from the Erawan/Platong group of of fshore gas fields are more substantial, at about: $10,000 \mathrm{bbl} /$ day. The Sirikit oil field at Lan Krabu produces about 15,000 bbl/day. No increase in production is expected.

In 1986 , the refinery capacity in Thalland was $194,000 \mathrm{bbl} / \mathrm{day}$, and the average production rate was $186,400 \mathrm{bbl} / \mathrm{day}$. About 63 percent of these products was used in the transportation sector, 13 percent in manufacturing, 8 percent in agriculture, and 8 percent by EGAT.

\subsubsection{Renewables}

Thailand intends to maximize development of indigenous conventional reserves but also increase the development of alternative energy resources, including bagasse, biogas, and geothermal. A resource already used to some extent for power generation in the private sector is rubber tree waste. These are the trees removed for new plantings. Another resource for which use is only now being planned is sugar cane trash. This is the residue left in the fields after harvesting. AID has examined the potential for using sugar cane trash in the South for local power needs. An AID study identifled a capability to provide $260 \mathrm{MW}$ of year-round power, from which a surplus can be sold to the grid at a price that fits EGAT's long-term marginal cost.

\subsubsection{Energy Transportation Infrastructure}

The Thai government's approach to the transport sector is determined by two main considerations: the $n$ ar completion of the national highway system and energy 
conservation. The former consideration dictates a slowdown in highway spending and a shift toward concentration on provincial and rural roads, and tuw' id improved maintenance and rehabilitation of the entire road system. On the other hand, energy efficlency in the transport sector, which accounts for about 40 percent of petroleum product consumption in Thalland, is expected to be improved by a shift from the road subsector to rall and water transport. This shift is favored on the premise that past heavy investments in roads were justifled only by previously cheap oil, discouraging the development of alternative, more energy efillolent modes of transport.

\subsubsection{Latand Transport}

The network of paved roads has expanded significantly, from an estimated $8,500 \mathrm{~km}$ in 1962 to $130,000 \mathrm{~km}$ in 1980 , consisting of $14,000 \mathrm{~km}$ of national highways, $30,000 \mathrm{~km}$ of provinclal roads, and $85,000 \mathrm{~km}$ of rural loads. Correspondingly, the vehicle fleet has also grown from about 300,000 to about 2 million over the same period. In contrast, the rallway network, totalins 3,800 route-km, hardly expanded during that same period. Road freight and passenger traffic grew on the order of 7 to 9 percent per annum, rallway passenger traffic grew by 8 percent per annum, and railway freight traffic grew by only 4 percent per annum despite subsidized tariff support. Significant amounts of minerals currently are transported by rail.

Substantial expansion of public investments in transport modes other than road transport, and in particular in rallways, is being assessed. Road transport, which currently accounts for 80 to 90 pelcent of total traffic in Thalland, consumes about 95 percent of total fuel used in the transport sector. Therefore, increased efficiency, improved maintenance, and gradual fleet modification on roads are likely to save more energy than large and costly expansions in rallway service.

Significant road sector development is being accompanied by development of an efficient trucking industry in the private sector. Trucking is now the primary means of hauling lignite. Little, if any, lignite is moved by rail. Although a possibillty, no rail spurs have yet been planned to accommodate the new lignite discovery at Saba Yol.

\subsubsection{Water Transport}

To support industrial and regional development of the eastern seatoard area, a major deep-sea port is under construction at Laem Chabang. But no date is reported for its completion because of a relatively low growth in port demand in general. Although the government had planned to expand the deep-sea port at Sattahip, it has concluded that private industry would not be attracted to the upgraded port. 


\subsection{FINANCIAL, ECONOMIC, AND TRADE ISSUES}

\subsubsection{Impact of Financial, Economic, and Trade Issues}

Thalland is committed to trade and welcomes forelgn private investment. Thalland's pro-business stance, conservative flscal and monetary policies, abundant natural resources, skilled labor, and impressive infrastructure all help to create a generally good investment climate. Thalland had a steady economic performance in 1987 as the country moved closer to the threshold of a newly industrialized country. The 28 percent inerease in exports was the catalyst. in the 6 percent growth in real gross domestic product. One of the major objectives of the Slxth Natlonal liconomia and Social Development Plan is to ralse Thalland's level of development. In the near term, the Thai government will address the solution to the trade and domestic budget deflcit problems as well as ways to increase employment, manage problems of natural resources and environmental deterioration, and promote equity ainong its people.

\subsubsection{Financial Trends}

A set of key financlal indicators assists in measuring the viabllity of a country's economic activity and its future prospects for development. These key economic indicators include trade balance, current and capital acocunts, forelgn reserves, and exchange rates (Table 4). Thailand's total export/import levels are deploted in Figure 2. The 1986 levels by country are shown in Figure 3.

\subsubsection{Balance of Payments}

The balance of payments monitors a country's international economic activities. Balance of payments deficits may result from transitory factors, such as a crop fallure or a labol strike in a major export industry, or from more d-ep-seated and persistent causes, such as low productivity growth or strong cost-push inflationary forces. The current accoun; in 1987 ran a deficit, but capital movements into Thalland kept the balance of payments in a surplus a mounting to about U.S. $\$ 700 \mathrm{milll}$.

\subsubsection{Current Account}

The current account includes unllateral transfers and private remittances, in addition to the balance on goods and servlces or balance of trade. The decline in oil prices had a dramatic effect on Thalland's current account in 1986, and the terms of trade improved some 10 percent. There was a savings of approximately U.S. $\$ 1$ blllion on petroleum Imports. During 1986, the "Vlsit Thalland Year," tourist arrivals Increased roughly 20 percent, which also helped the current account run a slight surplus. In 1987, however, the current account reversed itself and ended with a defloit of U.S. $\$ 600$ million because of the sharp increase in imports sustaining the economic growth of Thailand. 
TABLE 4 Thailand: Key Economic Indloators (in millions of current year U.S. dollars, representing period averages, unless otherwise indicated)

\begin{tabular}{|c|c|c|c|c|}
\hline Indicator & 1984 & 1985 & 1986 & $1987^{\mathrm{a}}$ \\
\hline \multicolumn{5}{|l|}{ Income, Production, and Employment } \\
\hline $\begin{array}{l}\text { GDP at current prices } \\
\text { GDP at constant ( } 1972) \text { prices } \\
\text { Per capita GDP at current prices } \\
\text { Gross fixed capital formation at } \\
\quad \text { current prices }\end{array}$ & $\begin{array}{r}40,486 \\
14,586 \\
803 \\
9,678\end{array}$ & $\begin{array}{r}36,862 \\
13,018 \\
719 \\
8,551\end{array}$ & $\begin{array}{r}40,189 \\
13,902 \\
771 \\
8,875\end{array}$ & $\overline{-}$ \\
\hline $\begin{array}{l}\text { Personal incorne } \\
\text { Labor force (in thousands) } \\
\text { Unemployment rate }(\%)\end{array}$ & $\begin{array}{r}32,360 \\
26,380 \\
5.1\end{array}$ & $\begin{array}{r}29,641 \\
27,140 \\
6,1\end{array}$ & $\begin{array}{r}32,198 \\
27,910 \\
6.8\end{array}$ & - \\
\hline \multicolumn{5}{|l|}{ Money and Prices } \\
\hline $\begin{array}{l}\text { Money supply } \\
\text { Interest rates, commercial bank prime } \\
\text { Indiçes }(1976=100) \\
\text { Wholesale price } \\
\text { Consumer price }\end{array}$ & $\begin{array}{l}3,948 \\
16.90\end{array}$ & $\begin{array}{l}169.0 \\
194.1\end{array}$ & $\begin{array}{l}168.4 \\
197.7\end{array}$ & - \\
\hline \multicolumn{5}{|l|}{ Balance of Payments and Trade } \\
\hline $\begin{array}{l}\text { Gold and foreign exchange reserves } \\
\text { External public debt } \\
\text { Annual debt service, total } \\
\text { Balarce of payments } \\
\text { Balance of trade } \\
\text { Total exports, FOB } \\
\text { Exports to U.S. } \\
\text { Total imports, CIF } \\
\text { Imports from U.S. } \\
\text { Exchange rate } \\
\text { (baht per U.S. } \$ 1.00)\end{array}$ & $\begin{array}{r}1,695 \\
7,633 \\
2,033 \\
448 \\
-2,957 \\
7,413 \\
1,273 \\
1,0,370 \\
1,382 \\
23.64\end{array}$ & $\begin{array}{r}2,708 \\
9,478 \\
2,189 \\
459 \\
-2,130 \\
7,125 \\
1,401 \\
9,255 \\
1,048\end{array}$ & $\begin{array}{r}3,776 \\
11,015 \\
2,402 \\
1,278 \\
-386 \\
8,802 \\
1,576 \\
9,188 \\
1,314\end{array}$ & $\begin{array}{r}5,000 \\
- \\
- \\
-230 \\
10,500 \\
1,540 \\
11,730 \\
781\end{array}$ \\
\hline
\end{tabular}

astimated.

Source: Ref. 5 


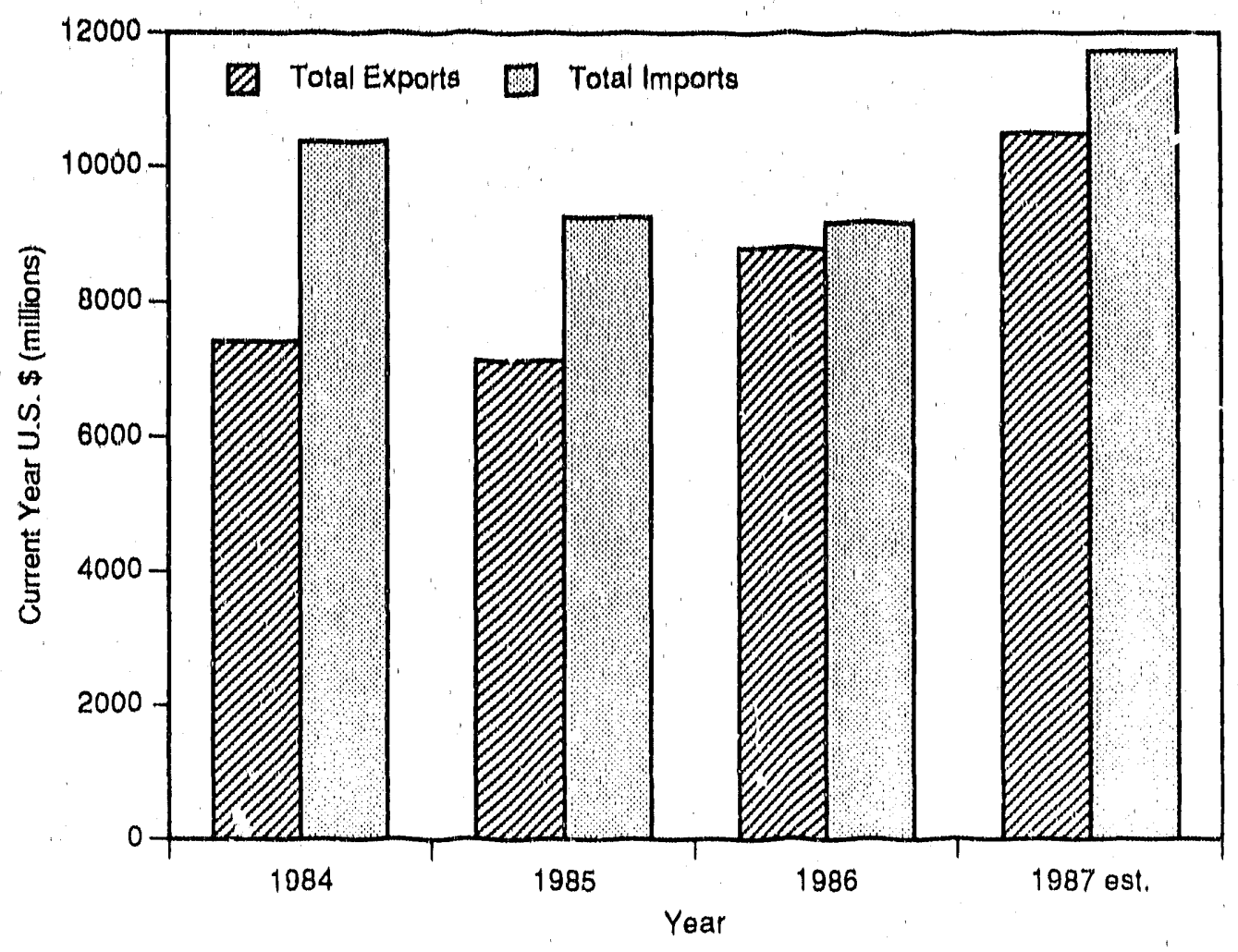

PIGURE 2 Thailand's Exports versus Imports (Source: Ref, 5)

\subsubsection{Capital Account}

The capital account encompasses the purchase of stocks, bonds, or real assets in a nation by another country. The Securities Exchange of Thailand attracted substantial forelgn investment in 1987. The exchange's net.worth in 1987 was U.S. $\$ 475$ million, compared with only U.S. $\$ 96$ million in: 1986 (16). The Thai government perceives that the most efficient way to attain long-term financial potential and mobilize equity funding from abroad is to develop Thailand's capital market. Of the registered capital investors seeking investment incentives between 1960 and 1985,28 percent represent foreign investment. Japan is the leading investor with 7.6 percent of cumulative registered capital and the United States is second at 4.7 percent, with Tajwan third at 2.6 percent (T'able 5).

\subsubsection{Exchange Rates}

Exchange rate variations allow individual countries to control their own money supplies. The main impetus to the steady rise in manufactured exports has been the decline of the U.S. dollar-linked baht. The first push came in 1984 with a 14 percent devaluation of the baht against the dollar. This was a difficult decision for Thai policymakers for whom the baht/dollar peg had been the foundation of monetary stability. The devaluation decision involved consiclerations of exchange rate stability and potentlal growth. The rate as of January 1988 was 25.5 baht per U.S. $\$ 1.00$. 


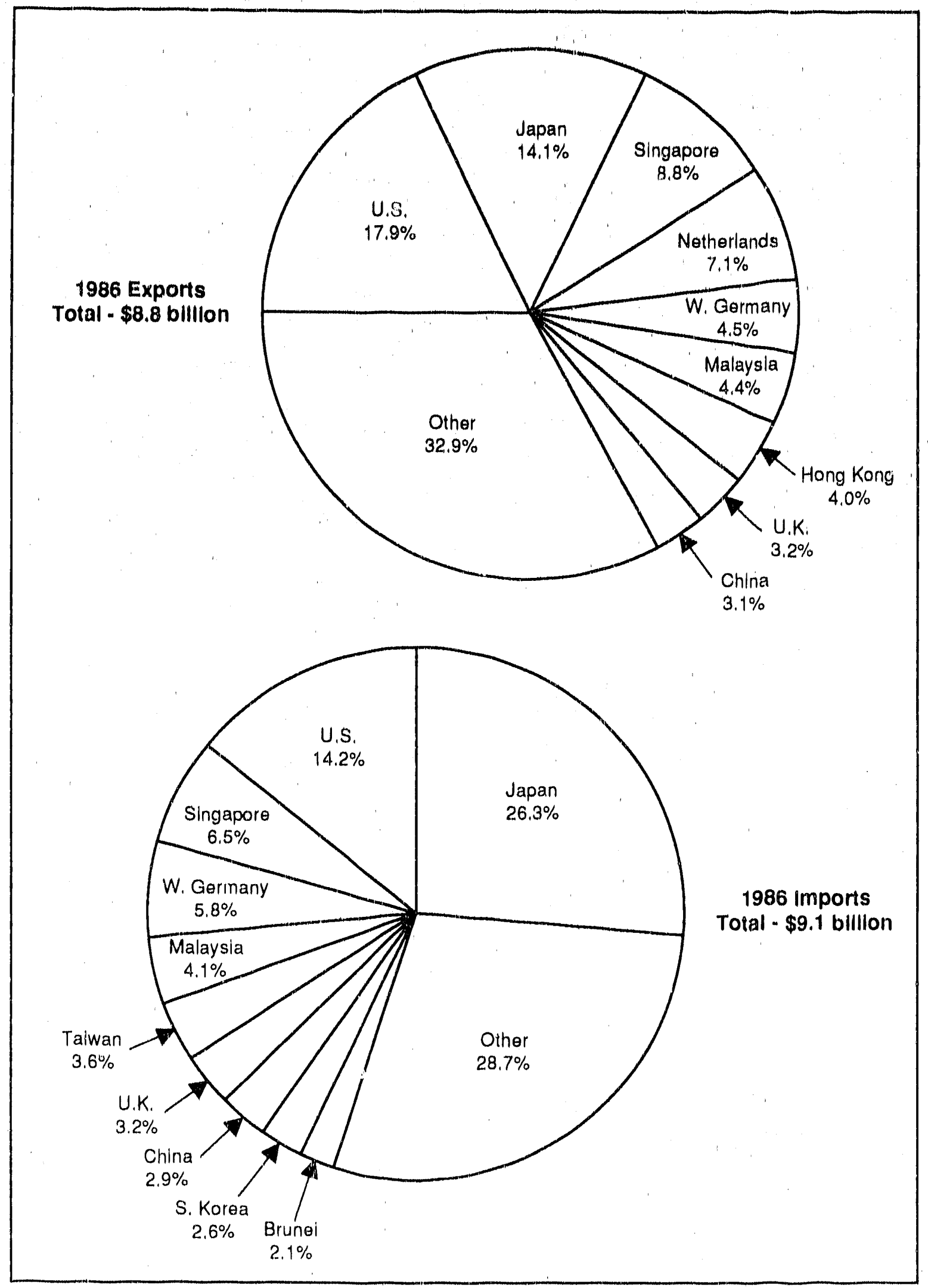

FIG URE 3 Thailand's 1986 Exports and Imports by Country (Source: Ref. 17) 
TABLE 5 Application for Investments (in millions of current year U.S. dollars)

\begin{tabular}{|c|c|c|c|c|}
\hline \multirow[b]{2}{*}{ Country } & \multicolumn{2}{|c|}{ Jan.-Sept. 1986} & \multicolumn{2}{|c|}{ Jan.-Sept: 1987} \\
\hline & $\begin{array}{l}\text { No. of } \\
\text { Projects }\end{array}$ & $\begin{array}{l}\text { Invest- } \\
\text { ment }(\$)\end{array}$ & $\begin{array}{l}\text { No: of } \\
\text { Projects }\end{array}$ & $\begin{array}{l}\text { Invest- } \\
\text { ment }(\$)\end{array}$ \\
\hline Europe & 26 & 128 & 74 & 516 \\
\hline Hong Kong & 12 & 47 & 36 & 132 \\
\hline Japan & 26 & 315 & 140 & 1,105 \\
\hline Taiwan & 32 & 121 & 125 & 380 \\
\hline USA & 18 & 97 & 37 & 372 \\
\hline
\end{tabular}

\subsubsection{Foreign Exchange Reserves}

Thailand's growth has been attained with price stability. The international reserves reached the level of about U.S. $\$ 5$ billion in the latter part of 1987 . Manufactured goods are becoming increasingly important sources of export earnings. Thailand is one of the few developing countries that is a net exporter of food products, and it ranks as one of the world's leading exporters of rice.

\subsubsection{Inflation}

The consumer price index, as a measure of inflation, has remained within the 2-3 percent range since 1984. Consumer prices, estimated to have risen by 2 percent in 1987, are expected to increase 3-4 percent in 1988.

\subsubsection{Incentives to Trade}

The Board of Investment (BOI), established in 1977 under the Investment Promotion Act, is the central investment planning authority in Thailand. The BOl's role is to encourage foreign and domestic investment, particularly in sectors and locations most appropriate for the country's overall economic development. While laws such as the Alien Business Law of 1972 prohibit majority ownership in a company by non-Thai individuals, there are numerous incentives designed to promote investment in the country. 


\subsubsection{Investment Promotion Act}

This act, administered by the BOI, defines priority areas for investment, identifies investment opportunities, and establishes the basis for "promoted" activities. Promoted entities may be granted certain guarantees and privileges including, but not limited to, the following:

- Exemption from or reduction in import duties and business taxes on imported machinery;

- Remittance of foreign currency covering the return of capital, profits, interest, and principal on foreign loans, royalties, fees, or other obligations; and

- Exemption from income tax on net profits for three to five fiscal years, depending on the size of the investment or number of workers.

\subsubsection{Industrial Free Zones}

Additional exemptions or reductions are generally available for enterprises, whether or not e:port-oriented, that are established in one of the nine Industrial Free Zones in Thailand. These zones are intended to disperse economic growth throughout the country and extend social services to the rural provinces. The BOI will grant benefits such as reductions of business taxes on the sale of products for a maximum of five years; exemption from import duties and business taxes on raw materials; and reduction by 50 to 75 percent of company income taxes for a further period of five years for companies located in a designated industrial estate.

\subsubsection{Exchange Control Act}

The BOI must approve the repatriation of investment funds, dividends, profits, and returns to those companies not covered under the two aforementioned scenarios. Approval to repatriate the investment funds, dividends, or profits of direct and portfolio investment, is granted in, but not limited to, the following cases:

- After deduction of income and other taxes and after appropriation of reserves;

- Transfer of up to 50 percent of the net profit for the first six months of the accounting year; and

- Transfers of large funds may be permitted only in installments so as to prevent undue fluctuations in the exchange rate. 


\subsubsection{Financing, Insurance, and Investment Options}

Various investor optiona exi for project financing. These financing options differ among lenders, but include long-term capital project financing, reimbursable grants on a cost-sharing basis; and direct short-term financing. The options will include financing sources such as government agencies, multilateral institutions, and private investment firms. These sources could include, but are not limited to, the following:

- U.S. government

Trade and Development Program (TDP)

Agency for International Development (AID)

Overseas Private Investment Corporation (OPIC)

- Multilateral institutions

International Finance Corporation (IFC)

Asian Development Bank (ADB)

World Bank (WB)

- Private investment firms

Commercial banks

Investment banking firms

Insurance for the investor may be obtained through select private banking and investment sources that have programs designed to secure investment risk. The key federal agency responsible for ens: ing the security of U.S. investment is OPIC. For qualified investors, OPIC offers isurance against inconvertibility of foreign earnings, expropriation or confiscalion, war, revolution, insurrection, and civil strife. OPIC also offers additional insurance and finance programs for U.S. investors in energy projects.

Alternative investment strategies, dependent on the extent of control and/or commitment desired by the investor, include, but are not limited to, licensing, partnerships, and turnkey project arrangements. A joint venture has not been recognized as a legal entity under the civil and commercial code.

\subsubsection{National Trade Objectives}

The Thai government's economic development policies are based on a liberal, export-oriented, free market philosophy. With sound monetary and fiscal policies and favorable investment incentives, the government is managing the economic expansion and growth so that the benefits reach an increasing proportion of Thai society.

\subsubsection{Monetary and Fiscal Policies}

In 1987, the financial system experienced excess liquidity. To maintain a check "on inflation, the Central Bank of Thailand is reducing liquidity in the inoney markets to halt an expected increase in commercial bank lending activities resulting from the recent 
economic growth. This constrictive monetary policy is intended to fuel domestic growth by increasing exports and the concomitant export earnings base by trying to limit an anticipated increase in imports resulting from increased domestic purchasing power. Fiscal policy is targeted to further reduce the largely yen and dollar debts. Preliminary plans for the 1989 fiscal budget anticipate that expenditures will increase by 11 percent and that the deficit will be in the range of 2.8 percent of gross domestic product.

\subsubsection{Development of Urban and Specialized Zones}

The development of the economic base in communities at the metropolitan level, in cities in the regional areas, and in new economic zones is considered an importan strategy for the future. Urbanization is a result of the changing economic structure of Thailand as a newly industrializing country. The Sixth National Economic and Social Development Plan sets a strategy for dispersing development of urban and new economic zones in different parts of the country. A wide range of tax incentives is providing the impetus for industry to locate in the Bangkok metropolitan area and to develop the eastern seaboard.

\subsubsection{The Treaty of Amity and the General Agreement of Tarifts and Trade (GATT)}

Under provisions of the 1966 Treaty of Amity and Economic Relations between Thailand and the United States, U.S. firms are accorded national treatment except when engaged in communications, transport, fiduciary functions, banking involving depository functions, or domestic trade in indigenous agriculture. The GATT provides Thailand with reduced tariff brirriers under the Generalized System of Preferences and with an orderly structure for iniernational trade with the United States and other GATT member nations.

\subsubsection{Other Factors}

The importance of providing adequate electrical power for the continued economic and industrial development of Thailand cannot be understated. Thailand is of importance to the United States for several reasons. Thailand is a strong, reliable ally of the United States in South Asia, and its stability and continued economic growth are important to U.S. foreign policy in the region. The United States has a vested interest in the ability of Thailand to service its debts to international and commercial banks. The repayment of these loans depends on strong and continuous economic growth, facilitated through expansion of the manufacturing sector. This growth requires dependable energy inputs to guarantee production and output. Also, the expansion needs of the Thai power sector provide opportunities in which U.S. technologies and services have a comparative advantage; therefore, significant trade opportunities exist (9).

Thailand is progressing toward and encouraging diversification to shift to a light manufacturing economy from a traditionally agrarian one. This shift will require energy generation that is reliable and able to keep pace with the growing manufacturing exports 
to meet the planned sectoral expansion under Thailand's Sixth National Economic and Sacial Development Plan.

See Appendix C for a listing of major U.S. companies operating in Thalland. 


\section{OPPORTUNITIES FOR ENERGY PROJECTS IN THAILAND}

Given Thailand's large lignite resources and a rapidly growing demand for electricity, the atmospheric fluidized bed combustor (AFBC) in sizes of $50 \mathrm{MW}$ and larger appears to be a viable candidate for electric sector opportunities in Thailand. This technology will allow this domestic resource to be used while meeting the Thal standards on sulfur dioxide $\left(\mathrm{SO}_{2}\right)$ emissions. If current practices are shanged so that private seotor power generation is expanded (some exists today under special circumstances), the AFBC technology in units of $25 \mathrm{MW}$ or greater may be competitive with other options avallable for this purpose.

Cost and performance information on standard coal plants for power generation, $\triangle F B C s$, and other CCT systems is provided in Appendix B. (The costs given in the illustrations are for installations in the continental United States.) Other technologies in this set, such as gasification, may also prove to have potential application in Thailand, depending on the magnitude and nature of the energy demand and the relative costs of competing fuels.

For example, another opportunity in Thailand concerns conversion of several aging oil-fired stations. These units include approximately 1,600 $\mathrm{MW}$ of capacity and are scheduled for renovation in the early to mid 1990s. Slagging combustors and coul-water mixtures (CWMs) appear to have some potential application in this situation. However, because of the characteristics of the indigenous Thai lignite, the coal used with either of these options would likely have to be imported. Nonetheless, such imports would replace imported oil, possibly at a competitive cost. These opportunities also will be briefly examined in the following sections.

\subsection{ELECTRIC UTILITY SECTOR}

As noted in Section 1.2, EGAT has significant capacity expansion plans calling for utilization of lignite-fired power plants, especially in the Northern and Southern Regions. In the very near term, EGAT plans to bulld a lignite-fired unit in the South. And, it has expressed strong interest in obtaining U.S. assistance in revising its prefeasibility study for a lignite-fired power plant there. Although this project was thought to be ready for award, the discovery of a large new lignite deposit in the vicinity of Krabi led EGAT to reevaluate the project. A U.S. AFBC unit is considered a good possibility.

For the medium term, EGAT's expansion plan calls for construction of more than 1,500 MW of new lignite-fired capacity by the mid-1990s, sustainable by domestic reserves. Thus, demonstration of U.S AFBC or other technology in a small-scale application could lead to significant scale-up potential and utllization opportunities in the numerous 300-MW plants to be built in the North. Also, support of the Thai effort to further the developrrient and use of the domestic lignite resources could encourage consideration of U.S. coal imports for facilitating plant start-up (and until domestic volume supply equilibrates with demand), for quality blending, or for coal demand in other sectors of the economy (e.g., in the cement sector). 


\subsubsection{Atmospheric Fluidized-Bed-Combustor Application for RGAT}

The Krabi Basin has approximately 20 million tonnes of proven lignite reserves. These reserves are of lower quality by world-class standards, in that they are characterized by high moisture, ash, and sulfur contents, and possess calorific value on the order of $4,360 \mathrm{Btu} / \mathrm{lb}$. Better quality lignite has been discovered at Sin Pun, about $60 \mathrm{~km}$ northeast of Krabi. Estimates exceed 10 million tonnes of recoverable reserves.

Design and performance criteria must adhere to the Thai National Environmental Board's requirements for approximately 70 percent $\mathrm{SO}_{2}$ removal; nitrogen oxides ( $\mathrm{NO}_{\mathrm{x}}$ ) emissions are expected to be within guideline limits, and particulates are expected to be controlled by a baghouse system.

Several options are presented in Table 6 for 50 - and 100-MW unit applications. These estimates are based on an annual fixed charge rate of 11.2 percent and levelization factors of 1.0 and 1.6 for lignite and oil, respectively. Note that the 50-MW AFBC and oil-fired options are essentially equivalent in cost. However, the AFBC urit would use indigenous rather than imported fuels, an important consideration. For the larger unit, the AFBC would fare better because of a better economy of scale.

The AFBC appears more economical than pulverized coal injection (PCI) with dry flue gas desulfurization (FGD). Because the Thai National Environmental Board will probably require a $F G D$ system, $P C I$ without $F G D$ is not a likely alternative. Furthermore, a PCI plant would not possess the flexibility to handle the varying,

TABLE 6 Electricity Cost by Option (costs in 1987 U.S. dollars)

\begin{tabular}{|c|c|c|c|c|c|c|}
\hline \multirow[b]{2}{*}{ Component } & \multicolumn{3}{|c|}{ 50-MW Unit } & \multicolumn{3}{|c|}{ 100-MW Unit } \\
\hline & $\mathrm{AFBC}$ & oil. & $\begin{array}{c}\text { PCI/ } \\
\text { dry FGD }\end{array}$ & $A F B C$ & Oil & $\begin{array}{c}\text { PCI/ } \\
\text { dry FGD }\end{array}$ \\
\hline $\begin{array}{l}\text { Capital cost }(\$ / \mathrm{kW}) \\
\text { Heat rate }(\mathrm{Btu} / \mathrm{kWh}) \\
\text { Fixed operating and }\end{array}$ & $\begin{array}{r}1,870 \\
11,730\end{array}$ & $\begin{array}{r}1,360 \\
10,490\end{array}$ & $\begin{array}{r}2,020 \\
11,560\end{array}$ & $\begin{array}{r}1,560 \\
11,730\end{array}$ & $\begin{array}{r}1,150 \\
10,490\end{array}$ & $\begin{array}{r}1,830 \\
11,560\end{array}$ \\
\hline $\begin{array}{l}\text { maintenance }(\$ / \mathrm{kW} / \mathrm{yr}) \\
\text { Variable operating and }\end{array}$ & 40.8 & 24.4 & 53.2 & 29.5 & 16.1 & 38.0 \\
\hline $\begin{array}{l}\text { maintenance (milis/kWh) } \\
\text { Levelizęd fuel cost }\end{array}$ & 3.2 & 1.6 & 4.0 & 3.2 & 1.6 & 4.0 \\
\hline $\begin{array}{l}\left(\$ / 10^{6} \text { Btu) }\right. \\
\text { Levelized electricity }\end{array}$ & 1.96 & 3.50 & 1.96 & 1.96 & 3.50 & 1.96 \\
\hline $\operatorname{cost}(\mathrm{mill} / \mathrm{s} / \mathrm{kWh})$ & 64.3 & 65.3 & $69 . ?$ & 59.5 & 62.0 & 66.3 \\
\hline
\end{tabular}

Source: Based on information from Ref. 4 
nonhomogeneous lignite quality anticipated from the Krabi basin. Thus, the AFBC is a strong potential candidate, meriting more detalled study.

\subsubsection{Metropolitan Rlectricity Authority Refurbishing}

In 1993, 240 MW of oll-fired capacity at the MEA's North Bangkok Station is scheduled to undergo renovation (11). In addition, $1,300 \mathrm{MW}$ is scheduled to undergo renovation at the South Bangkok Station in 1995. These overhauls offer the opportunity for replacement by slagging combustors or a CWM application.

Renovation costs have been estimated at $\$ 50$ million $(\$ 210 / \mathrm{kW})$ for North Bangkok and $\$ 60$ million $(\$ 46 / \mathrm{kW}$ ) for South Bangkok. These renovations will extend the lifetime of the plants by about 20 years. However, these plants would continue to be fueled with heavy fuel oll. Options for conversion to coal are also avallable, and costs can be estimated. For this purpose, we will assume that the life-extension renovation already planned can be modified so that no derating will occur (an optimistic assumption). We will also assume capital costs of $\$ 200 / \mathrm{kW}$ for $C W M$ and $\$ 300 / \mathrm{kW}$ for a slagging combustor and a $10 \%$ interest rate (Table 7).

An assumed levelized cost of oll was estimated at $\$ 3.90 / \mathrm{million}$ Btu, yielding a comparative electricity cost of $41 \mathrm{mills} / \mathrm{k}$ Wh for a renovated oil-fired plant. Therefore, the potential appears to exist for applying CWMs or slagging combustors in retrofitting

TABLE 7 MEA Options - Electricity Case (costs in 1986 U.S. dollars)

\begin{tabular}{lrr}
\hline \multicolumn{1}{c}{ Component } & $\begin{array}{r}\text { Slagging } \\
\text { Combustor }\end{array}$ \\
\hline Capital cost $(\$ / \mathrm{kW})$ & 200 & 300 \\
Heat rate (Btu/kWh) & 10,000 & 9,900 \\
Marginal operating and maintenance cost & 0.5 & 3.0 \\
above oil-fired unit (mils $/ \mathrm{kWh})$ & 3.50 & 1.60 \\
Fuel price $\left(\$ / 10^{6}\right.$ Btu) & 39.7 & 25.1 \\
\hline Adjusted cost of electricity (mills $/ \mathrm{kWh})$ & & \\
\hline
\end{tabular}

\footnotetext{
Based on using U.S. coal delivered at a cost of $\$ 40 /$ tonne, because indigenous 1 ignite is not appropriate for either technology.
} 
the Bangkok oll-fired units. Speclfic areas to be addressed, in addition to more detalled economic analyses, include:

- The extent of derating that may occur, partisularly with CWMs, and/or means to mitigate this effect; and

- The extent to which some of the planned renovation costs could be avoided or refocused as part of the specifle design process to convert to slagging combustors or CWMs.

\subsection{PRIVATE INDUSTRY}

Power demand is growing much faster than EGAT's supply, even with a steppedup investment program. Thus, the government is considering the approval of private power generation with possible sale to EGAT or third parties.

Opportunities for Industrial-park power generation may exist in the private sector, where gas-fired turbines are being considered. Estimates made for small Industrial lignite-fired bollers indicate that the cost of self-generated electricity is likely to be greater than the cost of buying electricity from EGAT. However, the AFBC has economic potential for self-generated power at sizes on the order of $25 \mathrm{MW}$ and above. Thus, small-scale applications of this technology appear to merit closer examination.

Finally, the cement industry has almost completely converted to coal. Approximately 500,000 tonnes/year are imported from the People's Republic of China, whereas about 150,000 tonnes/year come from Australia. Some options may exist to link a fossil energy technology project to U.S. coal imports for the cement industry, where possible trade or commerce incentives arise or where financial or technical assistance appears warranted.

\subsection{REMARKS}

From the foregoing analyses of the energy development needs of Thalland and the potential applicability of U.S. fossll fuel technologies, it appears that opportunities exist for energy project development. Possible clean coal technologies for utilization in That electric power generation include the atmospheric fluidized bed combustor, with slagging combustors or a coal-water mixture application for the North and South Bangkok renovations. 


\section{BIBLIOGRAPHY}

1. America's Clean Coal Commitment, a report by the U.S. Dopartment of Energy, Offloe of Fossil Energy, Washington, D.C., February 1987.

2. Browning, P., Thailand Weathers the Storms of World Trade While Others Falter, Far Eastern Economic Revlew, June 26, 1987.

3. Electric Power in Thailand, published by the National Energy Administration, Ministry of Sclence, Technology, and Energy, Bangkok, Thailand, 1986.

4. Feasibillty Study: Fluidized Bed Combustor $50 \mathrm{MW}$ Thermal Power Plant: Krabl, Thailand, prepared by Burns \& Roe Company for the Electriclty Generating Authority of Thalland, December 1987.

5. Foreign Economic Trends, prepared by American Embassy, Bangkok, Thalland, June 1987.

6. Improving International Competitiveness of U.S. Coal and Coal Technologies, National Coal Council, June 1987.

7. International Collaboration in the U.S. Department of Energy's Research and Development Programs: A Report of the Energy Research Advisory Board to the U.S. Department of Energy, prepared by the International R\&D Panel, DOE/S-0047, December 1985.

8. Oil and Thailand 1986, published by the National Energy Adrninistration, Ministry of Sclence, Technology, and Energy, Bangkok, Thalland, 1986.

9. Power Shortages in Developing Countries: Magnilude, Impacts, Solutlons, and the Role of the Plivate Sector, a report to Congress, U.S. Agency for International Development, Wushington, D.C., March 1988.

10. Private-Sector Power Generation in Thailand: Potential, Impediments, and Policy Issues, prepared by Hagler, Ballly, and Company for the U.S. Agency for International Development, Washington, D.C., November 1986.

11. Revised EGAT Power Development Plan (1987-2001), Volume 1: Main Report, Systems Planning Department of the Electricity Gerierating Authority of Thailand, November 1987.

12. Summary, The Sixth National Economic and Social Development Plan (1987-1991), The National Economic and Social Development Board, Office of the Prime Minister, Bangkok, Thalland, 1986.

13. Thailand Business Legal Hardbook, Offlce of the Prime Minister, Offlce of the Board of Investment, Thalland, 1987. 
14. Thalland: Economic Conditions in 1987 and Outlook for 1988, Department of Economlc Research, Bank of Thalland. 1987.

15. Thalland Energy Situation 1986, published by the National Energy Administration, Ministry of Bolence, Teohnology, and Energy, Bangkok, Thalland, 1986.

16. Thulland: Investors Guide, Offlce of the Prime Minister, Offlce of the Board of Investment, Thalland, 1987.

17. Thailand Nine Month Economlc Indicators, U.S. Embassy report, Bangkok, Thalland, December 1987.

18. The Role of Repowering in America's Power Ceneration Future, a report by the U.S. Department of Energy, Office of fFossil Energy, Washington, D.C., December
1987. 


\section{APPENDIX A \\ SCREENING OF CANDIDATE COUNTRIES}

The "U.S. Fossll Fuel Teohnologles for Developing Countrles" project was Initiated by the U.S. Department of Energy, OfPloe of Fossll Energy (DOE/FE), In June 1987, to evaluate, anlalyze, Identlfy, und develop market opportunities for U.S. Possil fuel technologles for developing country power generation and/or industrlal utllization in the Aslan, Near East, and Latin Amerioan/Caribbean reglons. Thls effort is Intended to result in enhanced transfer of U.S. fossil energy technology and increased competitlveness of the U.S. fossll energy industry in developing countries.

Thls appendlx summarlzes the Initial soreening of candidate countrias, a task accomplished by Argonne. National Laboratory (ANL) through funding provided by DOE/FE and the U.S. Agenoy for International Development (AID). The approach used is presented In Figure A.1, with the Inltial results being detalled in Table A.1. The starting place was a llsting of 75 AlD-assisted countries.

The general objeatlves for evaluating candldate countries were formulated to Include the existence of conditions favorable to a coal-orlented project, the chance of successfully Implementing and completing the project, the opportunity for In-country repllation of a successful project, and the opportunity for transferring the knowledge and experlence related to the project to other countries. The purpose 0 : the standardized screening approach was not to ellminate judgment through the use of absolute scieens, but rather to provide a reasonable method for reducing the candidate list to an approprlate smaller group for further study. The criteria used were:

1. Country is a "prlority" AID-assisted country -- among the top 37 (upper 50 percent) reclplents of FY 1987 Development Assistance (DA) and Economic Support Funds (ESF), AND country recelves project-type assistance.

2. Country has proven coal reserves of more than 20 million tonnes OR country imported more than 10,000 tonnes of coal in 1984, OR country Imported U.S. coal in 1984, 1985, or 1986 .

3. County has Installed thermal capacity greatur than or equal to $100 \mathrm{MW}$.

4. Country has a history of high electriaity consumptlon growth (greater than 5 percent/year between 1973 and 1984), OR projections Indloate that future powor demand growth will be higher than 4 percent/year.

Eighteen countries in the Asian, Near East, Latin Amerlcan, and Caribbean rog inns passed all four criteria (Table A.1). In addition, Lamalca, which would have been ellminated by the low demand projection, was added to this list based on specific 
plans for this country to add $66 \mathrm{MW}$ of coal-fired generstion capacity in the early $1990 \mathrm{~s}$ and the recognition of recent high load growth and un tertaintles in demand projectlons. The countries that passed includes

$\begin{array}{lll}\text { Asian } & \text { Near East } & \text { Latin Amerloan/Caribbean } \\ \text { Bangladesh } & \text { Egypt } & \text { Bolivia } \\ \text { India } & \text { Jordan } & \text { Costa Rica } \\ \text { Indonesia } & \text { Morocoo } & \text { Dominican Republic } \\ \text { Pakistan } & \text { Tunisia } & \text { Eouador } \\ \text { Phillippines } & & \text { Guatemala } \\ \text { Thailand } & & \text { Honduras } \\ & & \text { Jamalca } \\ & & \text { Panama } \\ & & \text { Peru }\end{array}$

These 19 couritrles were examined in more depth than was possible for the 75 countries involved in the preliminary screening process. The 19 country profiles that were developed covered important technlcal, financial/economic, social/institutional, and other practical factors affecting the electrical generation and industrial sectors. Some of the important factors considered are listed in Figure A.1.

The result was identification of 10 countries that were the most favorable for further study in conjunction with the terhnology and vendor analyses to be conducted. Those countries ares

Costa Rica
Dominican Republic
Ecuador
India
Indonesia
Jamalca
Jordan
Pakistan
Philippines
Thailand

Subsequent discussions among DOE/FE, AID, and ANL led to an emphasis on three of the above countries for the development of more detalled country profiles and analysis of project opportunitles. These three countriet are Costa Rica, the Dominican Republic, and Thalland. 


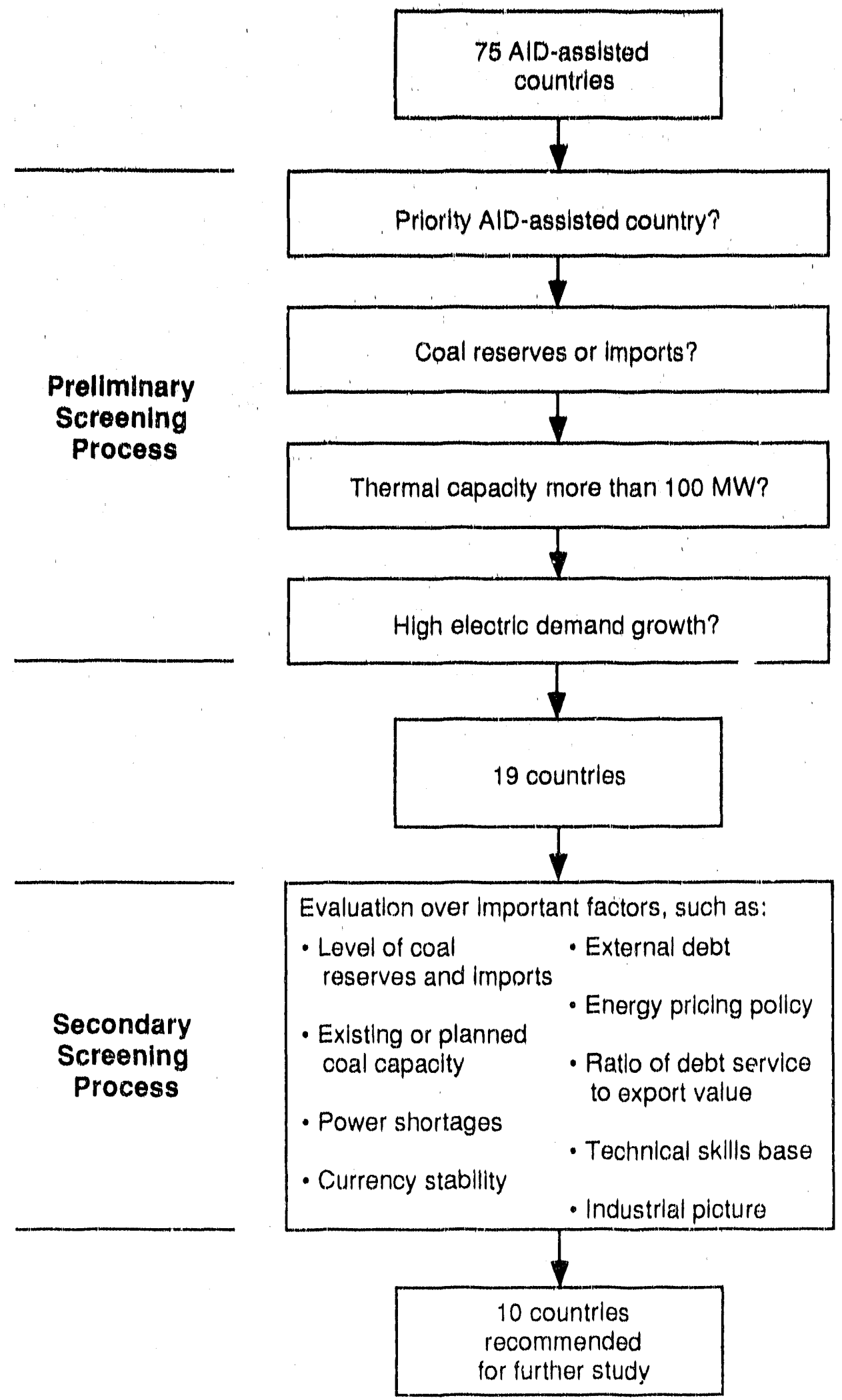

FIGURE A.1 Summary of Screening Process 
TABLE A.1 Countries Meeting Screening Criteria

\begin{tabular}{|c|c|c|c|c|c|}
\hline \multirow[b]{2}{*}{ Country } & \multicolumn{4}{|c|}{ Criteria } & \multirow[b]{2}{*}{ Pass } \\
\hline & 1 & 2 & 3 & 4 & \\
\hline Afghanistan & No ${ }^{a}$ & Yes & Yes & Yes & No \\
\hline Bangladesh & Yes & Yes & Yes & Yes & Yes \\
\hline Belize & No & No & No & No & No \\
\hline Bolivia & Yes & Yes & Yes & Yes & Yes \\
\hline Botswaisa & No. & Yes & Yes & & No \\
\hline Burkina Faso & No & No & No & Yes & No \\
\hline Burma & No & Yes & Yes & Yes & No \\
\hline Burundi & No & No & No & Yes & No \\
\hline Cameroon & Yes & No & No & Yes & No \\
\hline Cape Verde & No & No & No & No & No \\
\hline Central African Republic & No & No & No & No & No \\
\hline Chad & No & No & No & No & No \\
\hline Comoros & No & No & No & Yes & No \\
\hline Congo & No & No & No & Yes & No \\
\hline Costa Rica & Yes & Yes & Yes & Yes & Yes \\
\hline Cyprus & No & Yes & Yes & No & No \\
\hline Djibouti & No & No & No & Yes & No \\
\hline Dominican Republic & Yes & Yes & Yes & Yes & Yes \\
\hline Ecuador & Yes & Yes & Yes & Yes & Yes \\
\hline Egypt & Yes & Yes & Yes & Yes & Yes \\
\hline E1 Salvador & Yes & No & Yes & Yes & No \\
\hline Equatorial Guinea & No & No & No & No & No \\
\hline $\mathrm{Fiji}$ & No & Yes & Yes & Yes & No \\
\hline Gambia & No & No & No & Yes & No \\
\hline Ghana & No & No & Yes & No & No \\
\hline Guatemala & Yes & Yes & Yes & Yes & Yes \\
\hline Guinea & No & No & Yes & No & No \\
\hline Guinea-Bissau & No & No & No & Yes & No \\
\hline Haiti & Yes & Yes & No & Yes & No \\
\hline Honduras & Yes & Yes & Yes & Yes & Yes \\
\hline India & Yes & Yes & Yes & Yes & Yes \\
\hline Indonesia & Yes & Yes & Yes & Yes & Yes \\
\hline Ireland & No & Yes & Yes & No & No \\
\hline Israel & No & Yes & Yes & Yes & No \\
\hline Janaica & Yes & Yes & Yes & No & No \\
\hline Jordan & Yes & Yes & Yes & Yes & Yes \\
\hline
\end{tabular}


TABLE A.1 (Cont'd)

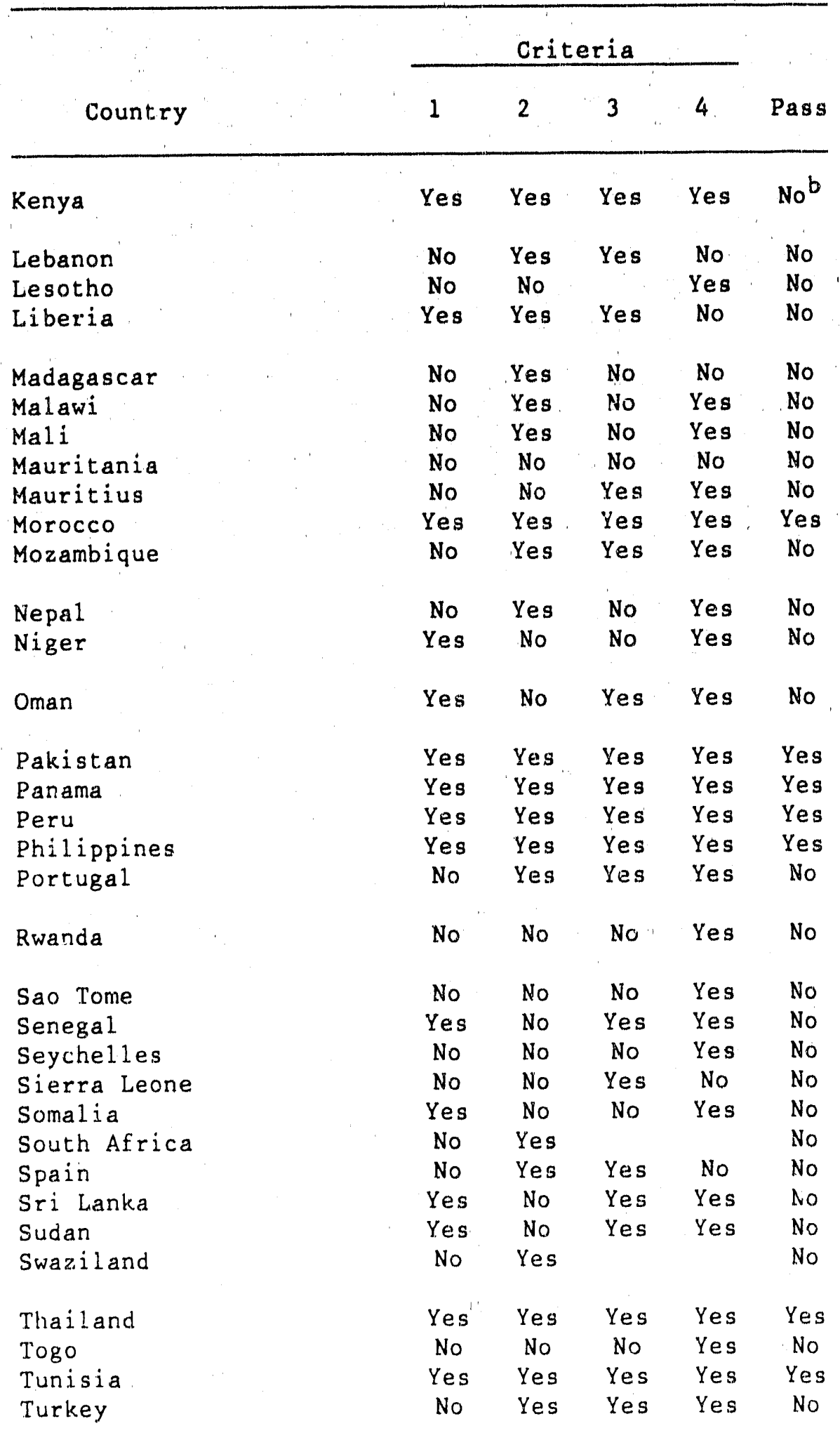


TABLE A.1 (Cont'd)

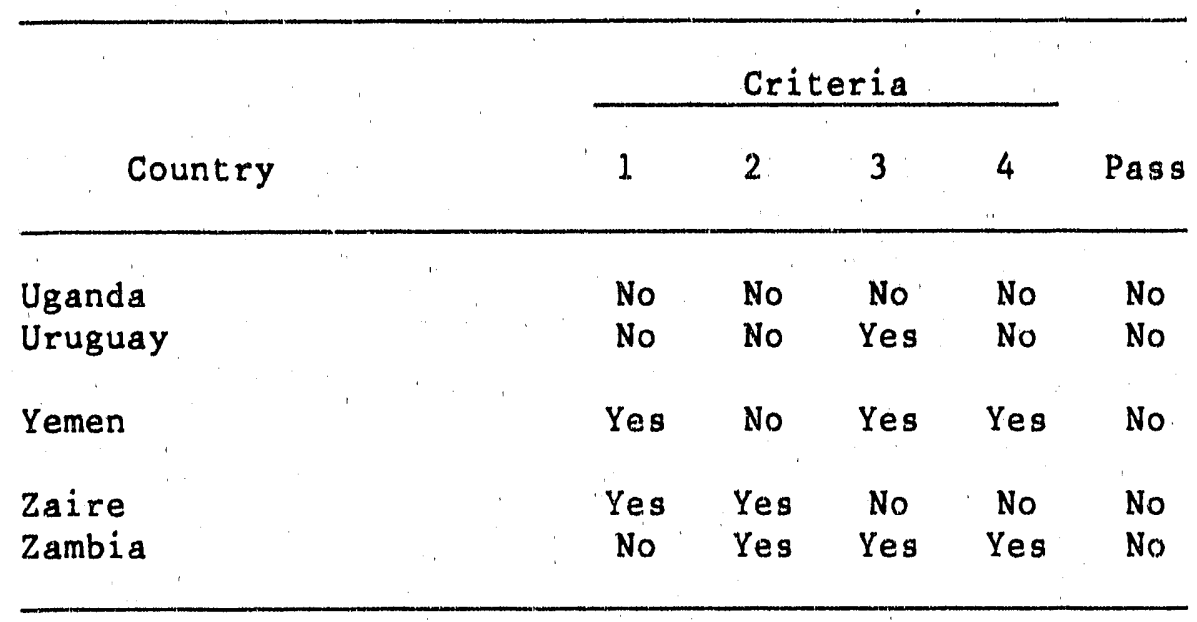

Legend:

$1=$ Top 50 percent of AID-assisted countries (top 37 recipients FY 1987 DA and ESF) AND receives technical/project assistance.

$2=$ Proven recoverable coal reserves greater than 20 million tonnes OR country imported more than 10,000 tonnes coal in 1984 OR country imported U.S. coal in 1984,1985 , or 1986 .

3 = Thermal power capacity greater than or equal to $100 \mathrm{MW}$.

4 = Past growth in electricity consumption greater than 5 percent/year (1973-1984) OR power demand projections greater than 4 percent/year.

${ }^{a}$ Humanitarian assistance projects implemented through the Afghan Resistance Alliance.

${ }^{b}$ Study is considering countries in the Asian/Near East and Latin American/Caribbean regions only. 


\section{APPENDIX B}

\section{AMERICA'S CLEAN COAL COMMITMENT}

\section{Executive Summary* ...}

Significant opportunities exist for new clean coal technologies because of past expenditures and a national commitment to future support.

For the last decade, the U.S. has been pursuing opportunities to develop advanced clean coal technologies. A solid technical foundation now exists, and using it, the nation has begun to embark on a major expansion of ejean coal technology development and demonstration.

Innovative clean coal technologies can generally be grouped into two categories: (1) retrofit technologies which can be used on existing plants to reduce emissions, and (2) repowering technologies that replace a significant portion of the original plant and of ten increase capacity while reducing emissions.

These emerging technologies offer significant improvements in cost-effective environmental performance, compared to previous alternatives. For example, advanced physical coal cleaning can potentially reduce $\mathrm{SO}_{2}$ emissions by $65 \%$, more than double the effectiveness of conventional techniques, and chemical and microbial cleaning may boost that effectiveness to $90 \%$ or more.

Retrofit techniques such as the limestone injection multistage burner, slagging combustors, gas reburning, in-duct sorbent injection, and advanced flue gas cleanup, used separately or in combinations, can control both $\mathrm{SO}_{2}$ and $\mathrm{NO}_{\mathrm{x}}$ and produce an environmentally safe waste product. Although the sulfur emission reduction potentials of some of these technologies are lower than conventional flue gas scrubbing, the reduction levels will likely be sufficient to meet possible future requirements for existing plants.

Repowering technologies, such as integrated gasification combined cycle (IGCC) and fluidized bed combustion (FBC) are able to reduce both $\mathrm{SO}_{2}$ and $\mathrm{NO}_{\mathrm{x}}$ emissions. In the case of IGCC, sulfur emission reductions greater than $99 \%$ have been achieved, while pressurized FBC is capable of lowering sulfur emissions by $95 \%$. IGCC technologies can also reduce $\mathrm{NO}_{\mathrm{x}}$ emissions by $40 \%$ compared to a conventional coal-fired power plant, while pressurized $\mathrm{FBC}$ technologies can achieve a $\mathrm{NO}_{\mathrm{x}}$ reduction of up to $85 \%$.

Many of these retrofit and repowering options are in the demonstration stage today. They will be technologically available either in the late 1980 s or early $1990 \mathrm{~s}$.

In addition to improved environmental performance, the new clean coal technologies, particularly repowering concepts, also offer substantial technical and econumic benefits. Repowering an existing power station, with IGCC for example, can

\footnotetext{
*'The following text is excerpted from Ref. 1.
} 
improve its power output by up to $150 \%$. This boost in power production of fsets most of the capital costs of refurbishing an aging plant, thereby resulting in only a minimal impact on the cost of electricity.

The Nation has built a solid R\&D foundation for clean coal technologies.

America's commitment to clean coal technologies began in hundreds of research laboratories and test sites in the $1960 \mathrm{~s}$ and $70 \mathrm{~s}$. In the aftermath of the 1973 oil embargo, the U.S. coal research progiam was driven largely by a goal of displacing liquid and gaseous fuels. Beginning in 1980, however, the program began to concentrate more on innovative technologies that could control $\mathrm{SO}_{2}$ and $\mathrm{NO}_{\mathrm{x}^{\circ}}$. The principal motivation in the decade of the 1980 s has been to address growing concerns about environmental issues, such as acid rain, and the compatibility of increased coal use with the nation's environmental goals.

From 1980 to 1985 , the U.S. - through both public and private financing - spent approximately $\$ 3.2$ billion on the development of new coal technologies. Of this, the research, development and demonstration of new coal-based technologies. to control $\mathrm{SO}_{2}$ and $\mathrm{NO}_{\mathrm{x}}$ accounted for more than $\$ 1.6$ billion.

The progress made as a result of these expenditures provides the technological basis for proceeding with full-scale demonstrations of promising new clean coal technologies.

The U.S. is rapidly becoming the world's showcase for clean coal technology.

America's [current and continuing] clean coal commitment is a national effort involving the federal government, state governments and private sponsors ... [Through this joint endeavor,] the nation is meeting its commitment to a cleaner environment in concert with increasing the use of American coal.

Coal's abundance ( $80 \%$ of the nation's known fossil fuel resources) makes it one of America's most important strategic resources in building a more secure energy future. Coal can be one of the nation's most productive domestic energy sources well into the 21st Century and beyond. If coal is to reach its full potential, however, economically competitive, advanced coal-using systems must be developed which are sensitive to diverse energy markets and site-specific factors as well as stringent environmental requirements.

America's clean coal commitment has the potential to:

1. Control large amounts of the $\mathrm{SO}_{2}$ and $\mathrm{NO}_{\mathrm{x}}$ released from coalfired power plants including those in the environmentally sensitive Northeast. 
2. Return economic benefits to American consumers by permitting clean energy to be generated without financlally constraining capital investments for environmental controls.

3. Retrofit and repower aging coal-fired power plants, particularly in the East.

4. Use high-sulfur coals, thereby avolding the social disruptions associated with massive coal switching, and

5. Reduce acid rain related emissions -- especially from aging power plants in the nation's northeast quadrant.

How rapidly these innovative clean coal technologies will be deployed depends upon many factors. Two of the important are (1) technology risk -- concern about the performance and reliability of the technologies - and (2) market demand -- influenced, for example, by the growth in demand for electricity and the future regulatory environment.

America's . . . clean coal commitment directly addresses the technological risk. By developing and demonstrating new technologies at commercial or near-commercial scale, the risk of commercial deployment is reduced. And it can give America a substantial marketing advantage in international trade by permitting the "packaging" of U.S. coal along with the technology to use it cleanly and efficiently.

America's clean coal commitment comes at a time when the nation's environmental consciousness - and that of our global neighbors -- is on the rise. It also coincides with the national goal established by the President to assure American competitive preeminence in the 21 st Century.

Perhaps most importantly, America's clean coal commitment represents a public and private sector partnership that can make coal an environmentally attractive fuel for the future, a fuel for energy security, and a fuel for continued economic growth.

\section{Technologies}

The illustrations and summary text on the next 10 pages have been reproduced from Ref. 1. 


\section{Conventional Coal-Fired Electric Power Plant}
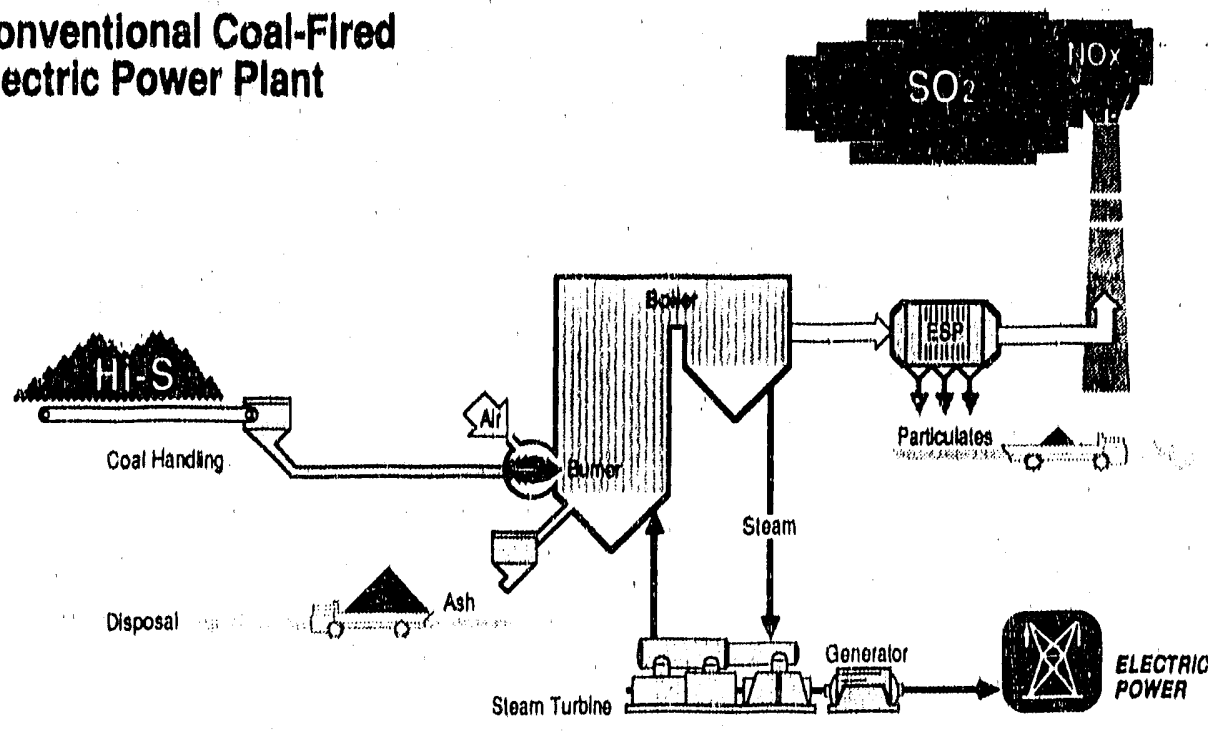

\section{Conventional Coal-Fired Electric Power Plant How Does It Work? \\ The conventional coal-fired power plant, which is usually equipped with particulate removal devices only, is used as the base technology in this briefing. The sulfur emissions trom this type of plant are tled to the sulfur content of its coal feed. The subsequent technologles described in this Appendix Involve $\mathrm{SO}_{2} / \mathrm{NO}_{x}$ emission control procedures. These technologies are compared with the base technology to highlight their attributes in terms of their $\mathrm{SO}_{2}$ and $\mathrm{NO}_{x}$ removal abilities and associated costs.}

Conventional coal-fired power plants may vary in size from less than $100 \mathrm{MW}$ to more than $2000 \mathrm{MW}$ and may be used in base-load and/or intermediale-load applications. The efficiency of the energy conversion from raw coal feed to the production of electricity is 35-38 percent. The cost of capltal for a new plant in the 350-1000 MW size is trom $\$ 1,500 . \$ 1,800$ per kW. With routine maintenance, a plant is expected to pertorm at design speclications for about 30 years. The operating and maintenarice costs range from 15.25 mills per kwh. The net heat rate for conventlonal plants range from $0,000-11,000 \mathrm{Btu}$ per $\mathrm{kw}$.

Coal combustion may be carried out in pulverized coal burners, cyolone furnaces, or varlous stoker and grate arrangernents. In pulverized coal boilers, pulverized coal is blown into the fumace. A signiticant amount of the Incombustlble fines leave with the combustion gases as fly ash, and the remainder is collected as bottr.m ash. In cyclone furnaces, coal is fed into the furnace tangentially, which increases the residence time and promotes thorough combustlon. However, the increased combustion temperatures also result in increased $\mathrm{NO}_{x}$ formation. In stoker-flred bollers, coal enters the firebox on moving grates. The combustible gases ignite and generate steam in the boller. The solids continue to burn as they travel through the furnace loward the ash collector at the end of the grate.

Heal from the combustion gases is transferred to the water circulating in the boller lubes. After a series of heat exchange operations within the boiler, saturated or superheated steam is generated. This steam then exparids through a steam furbine, its velocity increases, and its temperature and pressure decrease. The high veloclly steam impinges on the lurbine blades causing rotation. The mechanical energy from the turbine is converted to electrical energy by the generator.

Conventional boilers have either a wet or dry bottom. In wet bottom design, when coal is burned ash, becomes molten and runs to the bottom of the boller. Hence, these bollers require coal with low ash fusion temperature. In contrast, in bolers with dry bottom designs, coal ash is not supposed to liquely; so, these bollers require coal with high ash fusion temperatures. Power plant coal pulverizers are also designed for specillo types of coal. If an alternative coal is more difficult to grind or contains too much ash, then the pulverizer cannot provide adequate fuel to the boller. Although coal sulfur content does not significantly impact combustion, It does impact the performance of electrostatic precipitators. For coals containing less than 1 percent sulfur. pertormance of an electrostatic precipitator designed for high sultur coals becomes lese effectlve. 


\section{CONVENTIONAL COALFFIRED GLLCTRIG POWER PLANT With Flue Gas Scrubber}

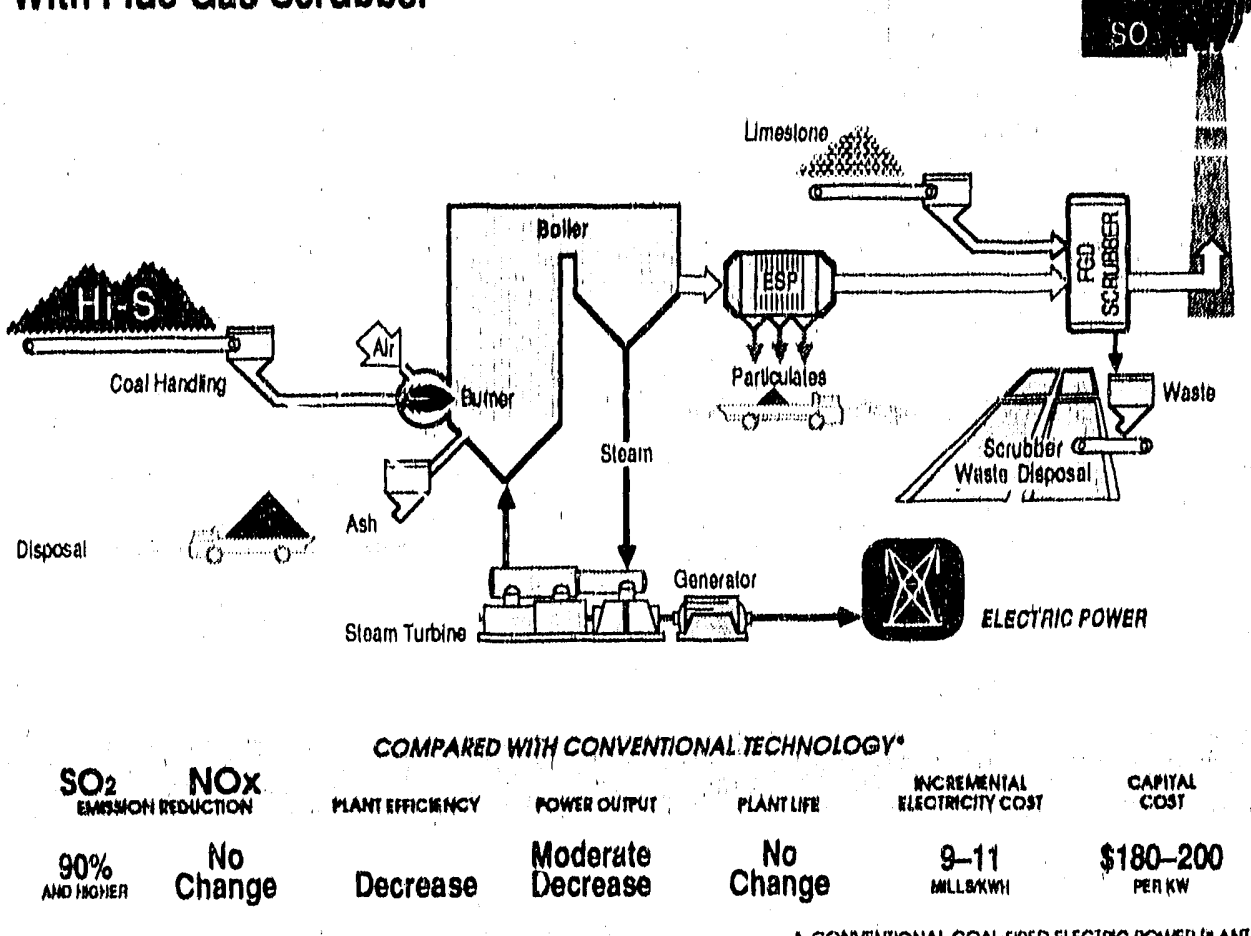

- CONVENTIONAL COAL.FIREO ELECTRC POWER MANT

\section{Flue Gas Scrubber}

\section{How Does it Work?}

Flue gas scrubbing is a commercial technology that has been utllized in many power plants, especlally those burning high-sultur coal. If involves reduction of $\mathrm{SO}_{2}$ from the combustion flue gases prior to atmospheric emissions by chemioal reachion with alkaline sorbents.

In a wet flue gas scrubber, the gas produced in coal combustion is typically sprayed with a slurry made up of water and an alkaline reagent, usually limestone. The $\mathrm{SO}_{2}$ in the flue gas reacts chemlcally with the reagent in the slurry forming calcium scifite and/or calcium sulfate, which is removed and disposed of in the form of a wet sludge having the consistency of toolhpaste. This wel sludge is composed of calclum sulfite, calclum sulfale, water, and unreacted limestone.

Scrubbers have been widely deployed, some removing mure than 90 percent of the $\mathrm{SO}_{2}$ emissions from high-sultur coals. Sorubbers are relatively costly to install and may cost as much as $\$ 250$ per $\mathrm{kw}$ capacity. Also, a flue gas sorubber is costly 10 operale. It consumes from 5-8 percent of the plant's output to run pumps, fans, and a flue gas reheat sytiem. It has high maintenance cosis and consumies a large amount of water $(500.2500$ gallons per minute tor a 500 MW unit). Further, there are reliability problerns due to plugging and fouling of the equipment and corrosion of fans and downstream ductwork. Large space is required to handle sorubber waste--typically one aore-toot per MW per year.

An allernative approach is the dry scrubber, or spray dryer. In a dry scrubber, the reagent slurry.-usually lime--is injected into an absorber vessel in a finely atomized form. The droplets evaporate in the hot gals, leaving only dry, reacted particles for collection in a conventional baghouse or electrostatic precipitator.

Although the dry scrubber is simpler, it has not been used successtully on high-sultur coal which may require 90 percent control. A dry scrubber may, in fact, be more costly than a wet scrubber, due to the increased cost of the reagent, for grass roots installation.

\section{What Are Its Attributes?}

- The wet flue gas scrubber can achleve over 90 percent $\mathrm{SO}_{2}$ removal from flue gases. However, it is costly to install, operate, and maintain.

- $\mathrm{NO}_{\mathrm{x}}$ emission is not affected by a wet or dry flue gas scrubber.

- Flue gas scrubibing reduces the overall afficiency of a coal-fired power plant from 35.38 percent 1032.35 peroent

- Large amounts of scrubber sludge are produced (in the order of 1 acre-loot per MW per year). Theretore, sludge handiling requires large amounts of space 


\section{CONVENTONALL COALFFILED GLECTRKC POWER PLANT With Advanced Flue Gas Cleanup}

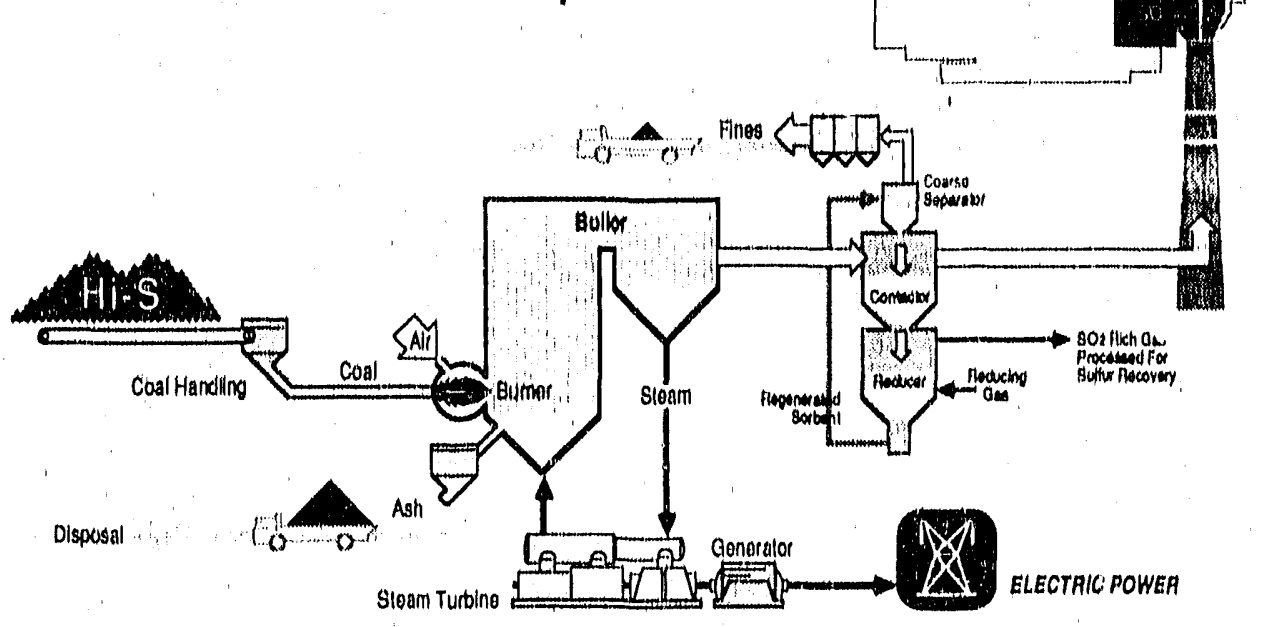

\begin{tabular}{|c|c|c|c|c|c|c|}
\hline \multicolumn{7}{|c|}{ COMPARED WIHH CONVENHIONAL RECHNOLOCY } \\
\hline $\mathrm{SO}_{2}$ & $\begin{array}{l}\text { NOX } \\
\text { averlow }\end{array}$ & PLANT EFAC:KMCY & rOWER OUIPUT & munturt & $\begin{array}{l}\text { MUCMENENIAL } \\
\text { ELIFCRECIY COSY }\end{array}$ & compts \\
\hline $\begin{array}{l}90 \% \% \\
\text { ANO HOKER }\end{array}$ & High & Decrease & $\begin{array}{c}\text { Small } \\
\text { Decrease }\end{array}$ & $\begin{array}{c}\text { No } \\
\text { Change }\end{array}$ & ${ }_{10-12}^{10-12}$ & $\$ 175-190$ \\
\hline
\end{tabular}

\section{Advanced Flue Gas Cleanup}

\section{How Does It Work?}

There is a great deal of aclivily involved in the development of advanoed flue gas oleanup clevices. A number of processes are under development. Examples of the types of processes under development include the use of electron beam radiation tor process entiancement and the use of metal oxides both for $\mathrm{SO}_{2}$ control and as a calalyst for the selective calalytio reduotion of $\mathrm{NO}_{\mathrm{x}}$ by ammorila. These processes are primarlly applicable to grass roots unils but may also provo uselul tor the retrofit of existing units.

The copper oxide fluldized bed process is undergoing proot of concept tesing at the present lime. Alumina spheres are coated with copper oxide and suspended in a bed that is lluidized using the flue ges laden with $\mathrm{SO}_{2}$ and $\mathrm{NO}_{x}$. The copper oxide reacts with $\mathrm{SO}_{2}$ to produce oopper sultate, which is combined with natural gas lo regenerale the oopper oxide. The $\mathrm{NO}_{x}$ reacts with ammonla (in the presence of copper sulfate, which serves as a catalyst) to produce molecular nitrogen. The moving bed contactor, also under development, is less mature but potentially cheaper than the fluid bed contactor.

Electron Beam Processes present alternate approaches that appear to be attractive. Irradiation of flue gas with electron beams produces, under the proper lemperature and humidity conditions, an abundant supply of lige radicals, ions, monoatomic species, and secondary electrons which promote the oxidation of $\mathrm{SO}_{2}$ and $\mathrm{NO}_{x}$ lo sulfurlc and nittic acids, respeotively. Two separale processes based on this phenomenon have been under development. The first uses a lime spray dryer upstream of the electron beam chamber. The second uses ammonia injectlon to reaot with the acids and form ammonium salts.

In the first approach, part of the reaction is between the flue gas and lime slurry in a spray dryer. Efliciency is improved in: an electron beam chamber, and the reactions are completed in a fabric filter baghouse. In the second approach, the flue gas is irradiated in the presence of ammonia.

\section{What Are Its Attributes?}

- Il is capable of reducing $\mathrm{SO}_{2}$ and $\mathrm{NOx}$ emissions by 90 percent.

- It is capable of achieving high reductions in $N D_{x}$ ornissions; more than other retrofit lechnologies

- Whille initlally developed tor new applications, II can be economically competitive in certain retrofit applications, particularly where deep $\mathrm{NO}_{x}$ removal is required.

- Il is capable of either regeneratling the sorbent or producing a fertilizer (E.beam ammonia).

- Unlike flue gas scrubbers, it does not produce large quantities of scrubber sludge. Hence, even though the capital costs are in the same range as those for flue gas sorubbers, the overriding advantages are many. 


\section{CONVENTIONAL COAL.HIRED RLECTRIC POWGR PLANT With Limestone Injection Multistage Burner (LIMB)} Or Slagging Combustor

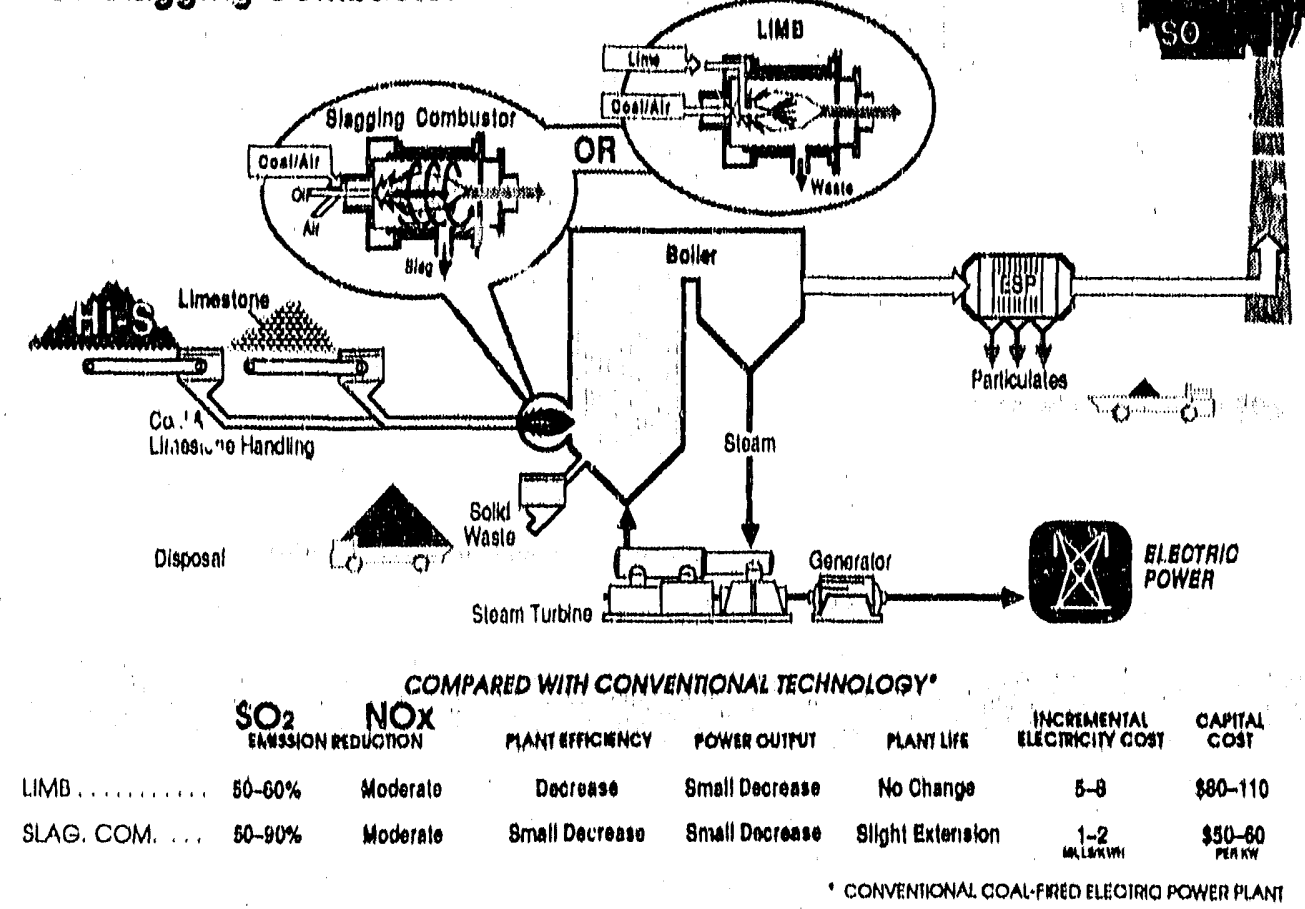

\section{Limestone Injection Multistage Burner or Slagging Combustor}

\section{How Does it Work?}

The slagging combustor is an advanced devioe that will control or remove objeotlonable sulfur and parlloulate matter from coal.derived fuel belore it is injected into relrofilted toilers or heatere. Although these combustors are primarily Interided for retrofit applications, they will also be appliloable and approprlate for incorporation into the design of new facilitles that can utilize their compact size and llexibility of coal use. The limestone injectlon mulligtage burner (L.IMB) approach is identioal in application to retrolit and new installations as is the slagging combustor. The coal, elther as a dry pistverized luel or as a coal llquid mixture, is led into the combustor in the conventional manner (pulverized coal liring) or pumped under pressure and injecled as a slurry.

In the slagging combustor, the fuel is injecled radially from a contral injector, whereas the air is fed tangentially around the periphery. The Interaction of the alr moving circumlerentially and the coal partioles or draplets moving axlally and radlaly outward results in a continuous llow of air aoross a burning particle, thereby providing more rapid and efflolent combustlon of the coal. Points of alr injeotion can be placed in suoh a inanner as to provide staged combustion lo control $\mathrm{NO}_{x}$ formation.

Sullur dioxide control is achieved by the injectlon ol alkall compounds, e.g. limestone, during combustlon or with the luel. The slagging combustor controls partioulate emisslon by converting the ash into molton slagl whioh, logether with the solld sulfites and sullales produoed by the injection of limestone, are removed betore the hot gases enter the boller or heater passage areas. In the LIMB, the limestone is introduced into the combustor or into the combustion gases of a burner operating at a temperature thet produces dry ash. The particulates, including the reacled sorbent and sultur, are carried through the boller passageways and subsequently captured by elther a baghouse or eleotrostatlo precipltator belore exhalusting the flue gas 10 the almosphere through the slack.

\section{What Are Its Attributes?}

- There are no speoial coal handling requirements other than the addilion of a limestone feod system.

- The slagging combustor produces a mollen slag containing the ash and captured sullur as a solid waste prior to beiler entry.

- The removal of ash as slag rejection is $80-90$ percent.

- $\mathrm{NO}_{x}$ reduction is achieved by staged combustion.

- $\mathrm{NO}_{x}$ reduction of $50 . \%$ percent relative to wall-fired, pulverized-coal combustors is achioved.

- Slaggirig combustors have the potentlal to replace existing cyolone bolters, which are very high $\mathrm{NO}_{\mathrm{x}}$ ermitters.

- Coal lifuid luel can simplity fues storage, handingh, and loed systems.

- Injection of sultur sorbent either with the fuel or separately into the combustor or into the combustion gases aliminates ihe need for a llue gas desulfurization system.

- High-sulfur, high-ash, and low-fusion lemperalure coals can be used. 

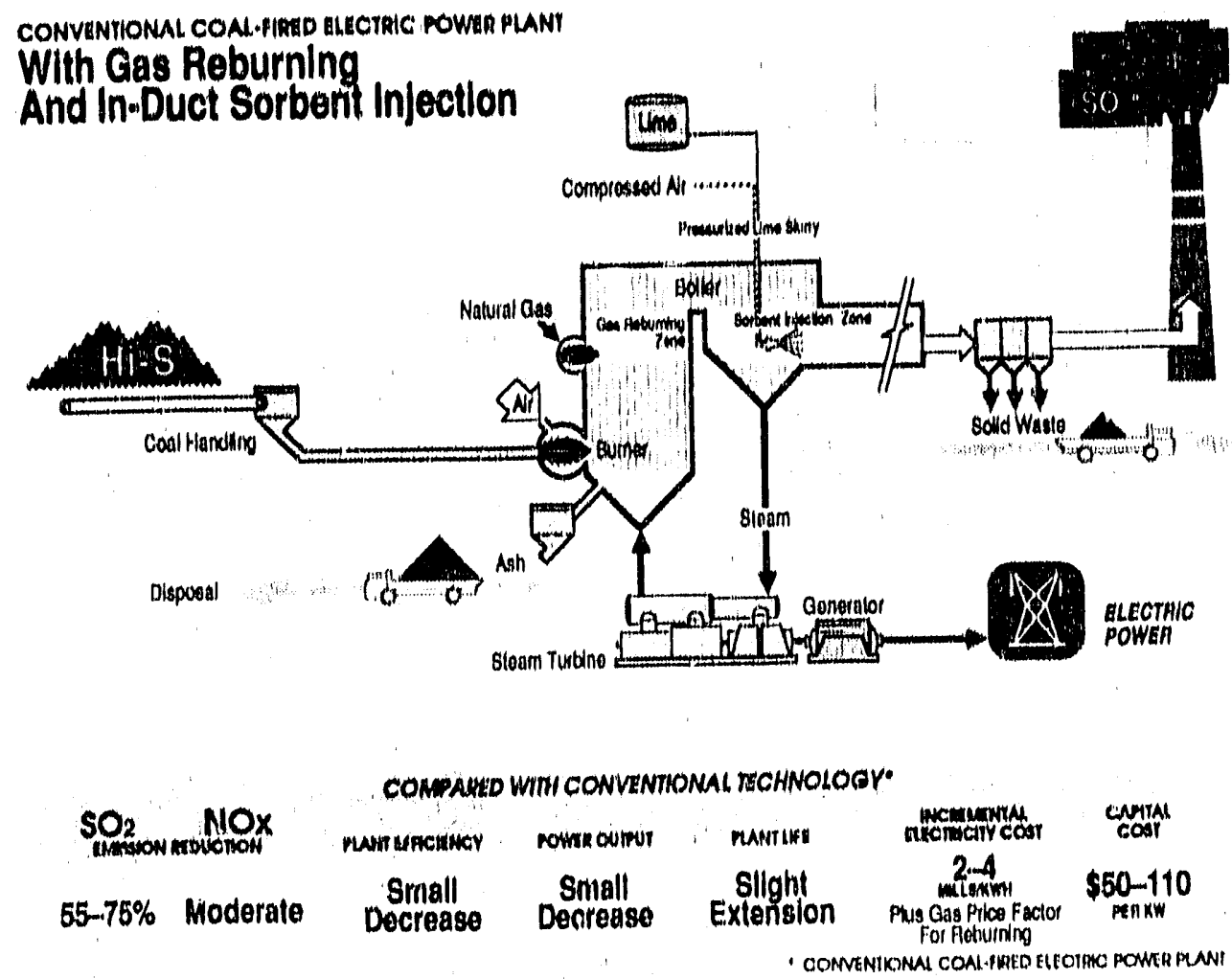

\section{Gas Reburning and In-duct Sorbent Injection}

\section{How Does it Work?}

Gus reburning uses a small anount (10-20 percent of lotal hel inpull) of natural gas whilo is injocted above the normal heat

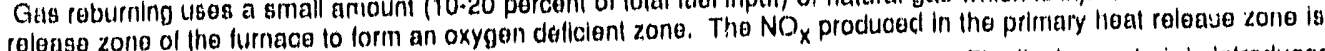

"raburned" in tho orygen deflcient zolle and partially reduced lo moleoular nitrogen. Finally, burnout air is introcluced above the reburning zone 10 complete the combustion process. Since the natural gas contains neither sulltur nor ash, omission of both are reduced in dirtot proportion to the amount of gas used.

In-ducl sorbent injection involves the spray injection of calclum based sorbents cluse to the conter of the duot and clownstrean oxpands, the from the combustion zone. The directon a rapldy absorbed by the spray draplets. The firer the sorbent dropleta, the more

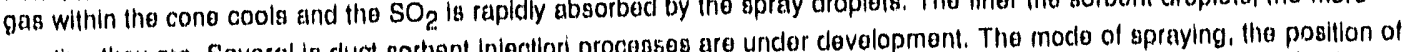
reactive they ale. Several in-duct sorbent injectlori procestes are under development. The mode of However, the basio the spray mechanlsm in the duct, and the rature of the sorbent may vary doponding 50 , is removed in the downstream particulates

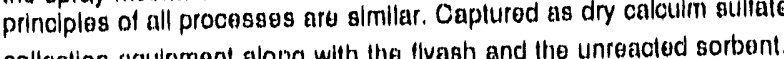

collectlon equipment along with the llyash and the untead

\section{What Are its Attributes?}

- A moderate amount of $\mathrm{SO}_{2}$ and $\mathrm{NO}_{x}$ feduction is obtained al a cost that is slgnificantly less than the cost lo use a scrubber.

- A dry and nontoxio solld waste is produced that can be disposed of easily.

- Il can eisily be retrolitted to an exlating unit without roquiring a major investment or a langthy oulago

- While there is a small decrease In efficiency due to the emall amount of energy needed to operale the an improvement in the operation of the boller because of the reduced loading of ash into the boller. 


\section{CONVENTIONAL COAL.PIRED GLECTRIC POWER PLANY With Advanced Coal Cleaning}

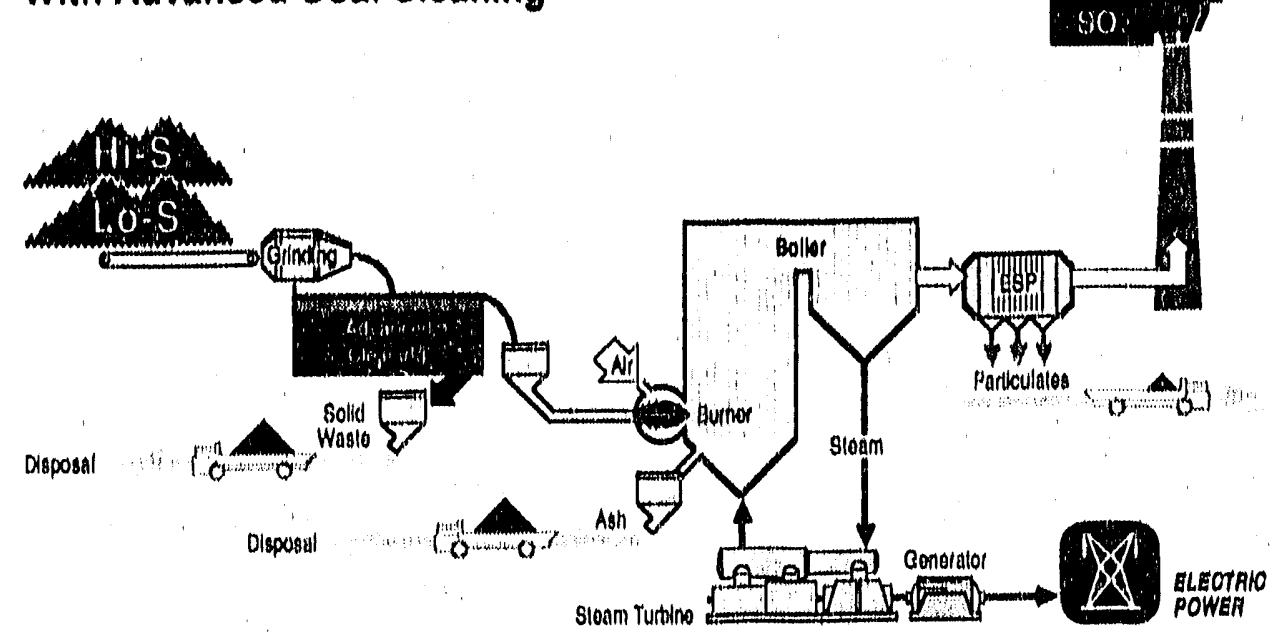

COMPARED WITH CONVENIONAL TECHNOLOCW

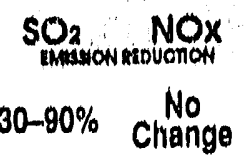

nowtroumil

No
Mawi Li:

Slight Exterision

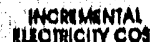

\section{6-21}

IMLaxmi

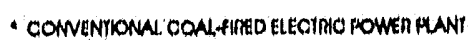

\section{Advanced Coal Cleaning}

\section{How Does it Work?}

Sulfur existo in onal in two bealc lorms, commonly aalled pyrilio and organlo. Pyritio sultur is iron pyrite whioh exista in the coal as disorele amall particles. Because this mineral looks like gold, it is sometimes reterred to as "lool's gold." Organlo sultur is composed of sulfur moleoules ahernioally bound to the complex coal molecule. Of the coal which is burned today, approximalely 36 percent is oleaned by coriventlonal coal cleaning plants. Conventlonal oleaning exiraots the heavler forms of mineral malter, such as ash and pyritlo sultur, trom the coal. Since the coal is lighter than the ash and pyrite, If can be

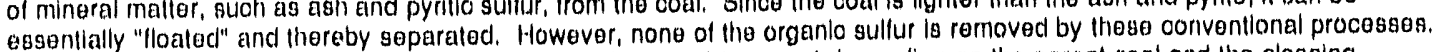
For those coals oleaned, the oulfur recluotion ranges from 10.30 percent depending on the parent coal and the oleaning lechnology applled. Coal cleaning technologies can be grouped into two categories: physloal and ahemlaal. Physical cleaning technologies, suah as those being used commerclally loclay, separate the ash and pyritlo sullur from the ooal using physical differenoes. Therefore, the redualion of sulfur emissions lo limiled to the percent of pyritio sulfur in the coal. Chemloal and microbial coal aleaning involves the introduction of chemical or mlorobial agents which react with the sulfur, inoluding organic sulfur, asti, and sometimes the coal itsell, to remove ash and sulfur. No ohemloal or mloroblal coal oleaning technology is now in commerclal use.

\section{What Are Its Attributes?}

- Chemical cileaning has the polential of removing over 90 percent of the sulfur from coal, but the processing oosts are greater than the onsts of physical techniques.

- Aoduced ash levels and improved coal qually have the potential of helping to ofleot the costs of deaning the coal (e.g., reduced transportation cos $\$ 9$, and improved powerplant avallabillty and rellability due to roduced ash levele).

- Now ooal cleaning plants would typically be bulli near coal mines.

- Advanced physioal oleaning lochnologies include several processes with the potentlal of ramoving 65 percent of the total sullur in coal. The ohemical technologiles range trom trealment with hol caustlo (capable of removing 90 percoent of the sulfur and 98 percent of the algh) to removal of organic sulfur using miaroorganisms.

- The waste trom coal cleaning consists of solld mineral malter and is typically disposed of at the mine silte.

- As nitrogen odides are lormea during combualion, coal oleaning does nol reduce $\mathrm{NO}_{x}$ emissions. 


\section{Coal Slurry Flred ELECTRIO POWEA PLANT}
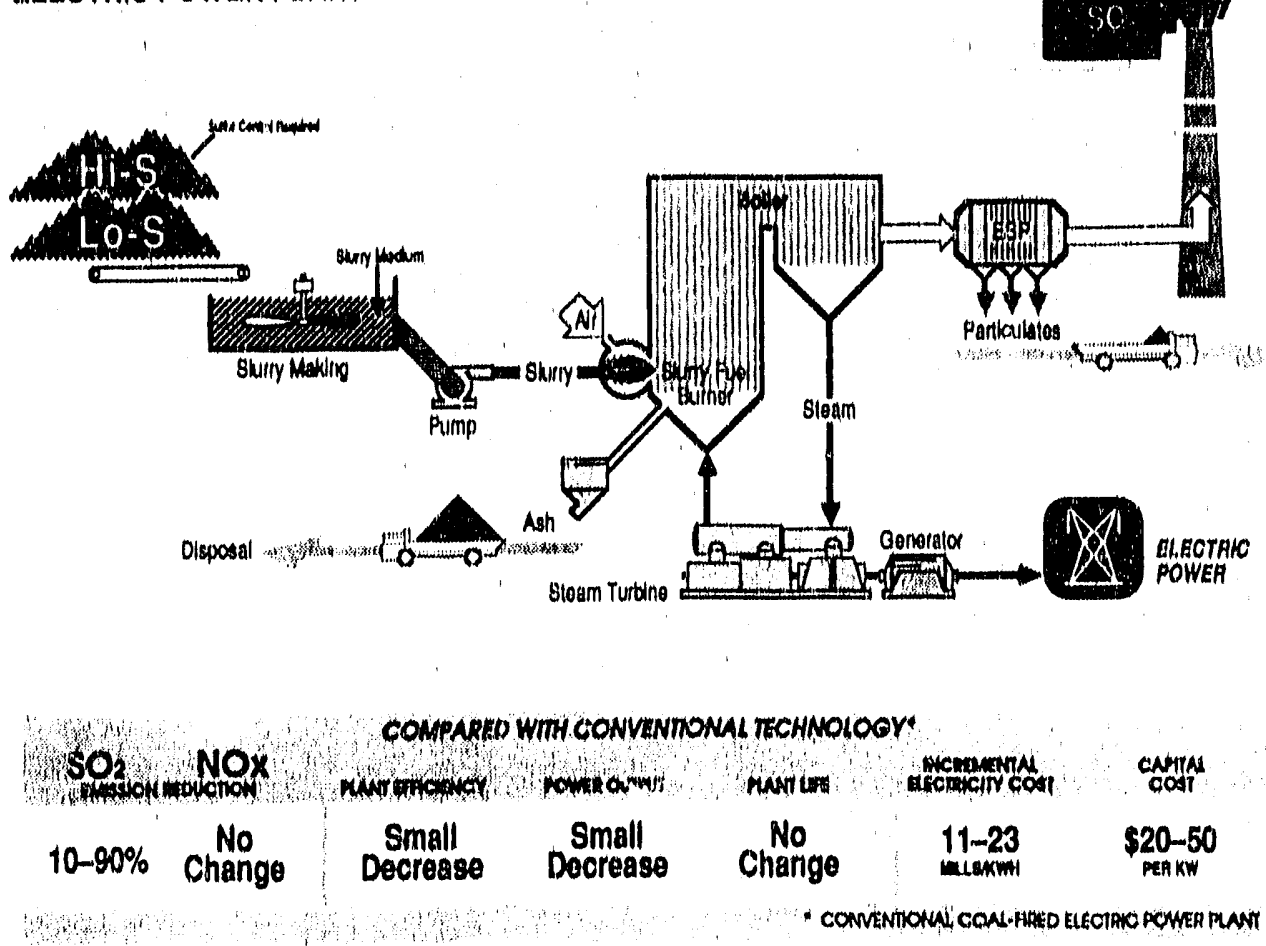

\section{Coal-Liquid Slurry Fuel}

\section{How Does It Work?}

The sluriy fuel burning system is not unilke a pulverized coal-fired boller, except that its leeding operation is easler and lis fuet relatively cleaner. Coal in the torm of a slurry is pumped under pressure into the burner manifold where it is injected into the combustion chamber. With the proper combustor design, high combustion eflicienoles can be achieved. Use of coal slurry fuels will not have any signilioant adverse effeot on syslem elficiency nor any adverse eflect on unil lite. The preparatlon and use of a coal slurry tuel may inorease the cost of ulilizalion; however, the advantages of onal slurry tuels, l.e., transportablity; ease of handling, satety, ease of feeding into the combustor, use of cleaner coal resulting trom the fuel preparallon process, etc. may offsel the efleots of increased utilization costs. Use of coal slurries prepared from slandard pulverlzed coal will necessitale the sarne pollutant contral processes as with pulverized coal-flred systems. However, most coal slurry fuels are produced as alean fuels, thus reducing to a minimum the pollution control requlements at the user site.

\section{What Are Its Attributes?}

- The luel preparation process achleves significant reductions in $\mathrm{SO}_{2}$ and partioulate emissions.

- It is possible to reduce $\mathrm{SO}_{2}$ ernisslons by more than 60 percent.

- It significantly reduces the quantily of waste produced at the user sile.

- It eliminates coal pile run-off pollution control requirements.

- It provides ease ol transporl, storage, handling, and leeding.

- Increased injection pressures permit beller fuel dispersion and, subsequently, higher combustion intensity and, therelore, unit size reduction.

- Il provides for direct use in slurry form ol wet coals produced trom coal cleaning processes, without the added cost of coal drying required for pulverized lead systems.

- Il significantly simplifies the feed system of a pressurized fluidized bed combusilion system. 


\section{Integrated Gasification Combined Cyclo ELECTAIC POWER PLANT}

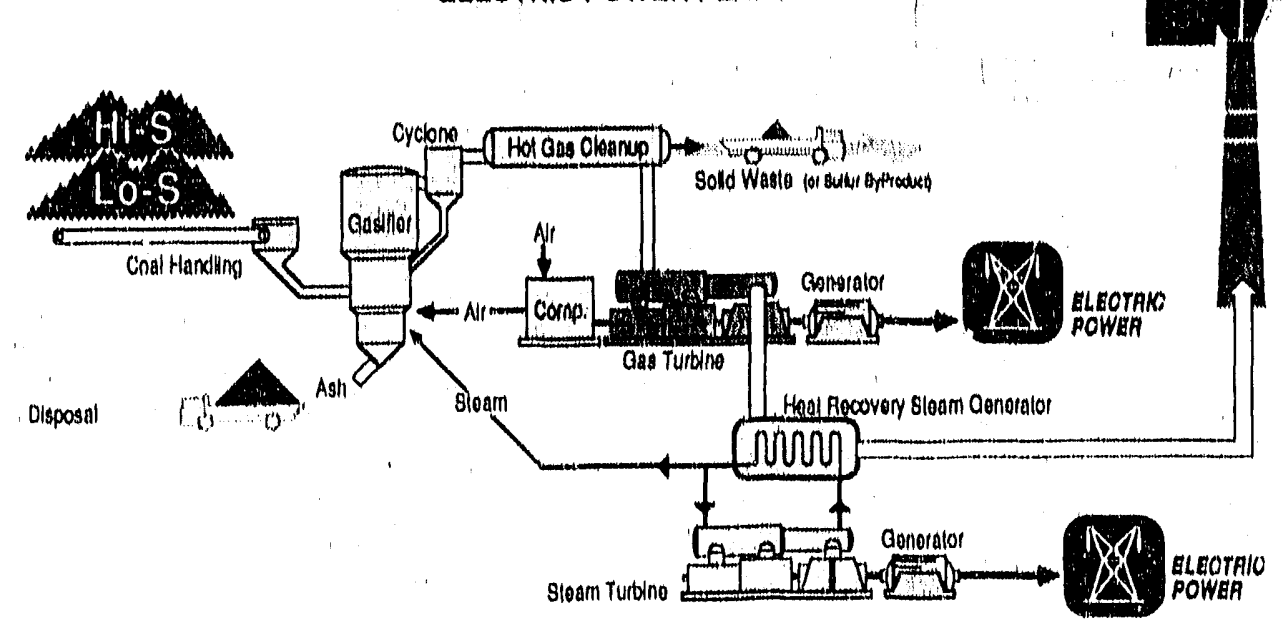

\begin{tabular}{|c|c|c|c|c|c|c|}
\hline & & COMPARE & WTH CONVENT & NAL TECHNOLC & & \\
\hline $\mathrm{SO}_{2}$ & $\operatorname{NOX}_{\text {Mnouction }}^{\text {Nox }}$ & PUNTEFHCIENCY & rowith outruy & Rant uFn & 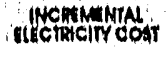 & CAMjen \\
\hline & Moderate & $\begin{array}{l}\text { Moderate } \\
\text { Increasse }\end{array}$ & $\underset{\text { WOREAAE }}{50-150 \%}$ & $\begin{array}{l}\text { Moderaye } \\
\text { Extension }\end{array}$ & $\begin{array}{l}1,-2 \\
\text { mLLaxim }\end{array}$ & $\$ 1,100-1,300$ \\
\hline
\end{tabular}

\section{Integrated Gasification Combined Cycle (IGCC)} How Does it Work?

in a gasification reactor, coal is reacted with air and steam at a high lemperature. This causes the coal to be converted to a gas composed predominantly of hydrogen, carbon monoxide, and hydrogen sulfide. The ash, which le not gasified, can then to easily separated. The sullur in the coal is converled into hydrogen sulfide which eveniually oan be oonverted to olomerital sultu or some solid waste malerial. The cleaned gas silleam lo combusted in a gess lurbine. Whillo the gas turbine is similar to sullu or some solid waste mblerial. The deaned gas silearn lo combusted in a geas turbine. Whe combusted gases which exit the gas lurbine are still hot enough to generale steam whlch can then run a sloam turbino 10 produce additlonal eleolricity. The name "combined cyole" is derived trom the lact that boll gas and sieam lurbines are in the system.

\section{What Are Its Attributes?}

- There are no special ooal handing requirements other than the potentlal to add llmestone to the coal feed.

- Gases require hot particulate and sultur oleanup betore entering the gas turblne. No flue gas oleanup is requlred.

- Combined cycle plants, in addition to inoreasing the efllolency of energy produotion, can be composed of standardized modules in 100.200 MW sizes applicable to large and small utilites. This leads to easler Installatlon, less construotion ime, and relatively lower cost without the usual economy of scale penaliles.

- The waste generated is a dry, benign solid thal can be disposed of easily or usefully employed $\left(\theta, g_{1}\right.$, elemental sulfur or material for road or building construation).

- The space required for IGCC expansion is of the same order of magnilude as would be required tor a sorubber.

- It is relatively non-sensiltive to coal feedstouk.

- Sullur removal levels of over 99 peroent have been demonetrated. These emlsaion levels are well below the existing ernission standard of 90 percent removal for rew plants.

- Nitrogen cxide removal levels of 40 peroent have been demonstrated.

\section{What Repowering Potentlal Does IGCC Have For Targeted Plants?}

In repowering with IGCC, a gaslfier, gas stream olean-up unit, gas turbine, and waste heat recovery boller are added; In most cases, these replace the existing coal boller. The remaining equipment lo left in place, inclucling the sleam furbine arid electrical generator. The resull is an extension of plant llte to essentlally that of a new plant, an inarease in efflciency from a nominal 35 percent to over 40 percent, and an increase in overaill plant output of $50-150$ peroent with slgniflicantly roduced overall emissions. The inoremental cost of the additional oapaoily lo low compared to the cost of a new plant. 


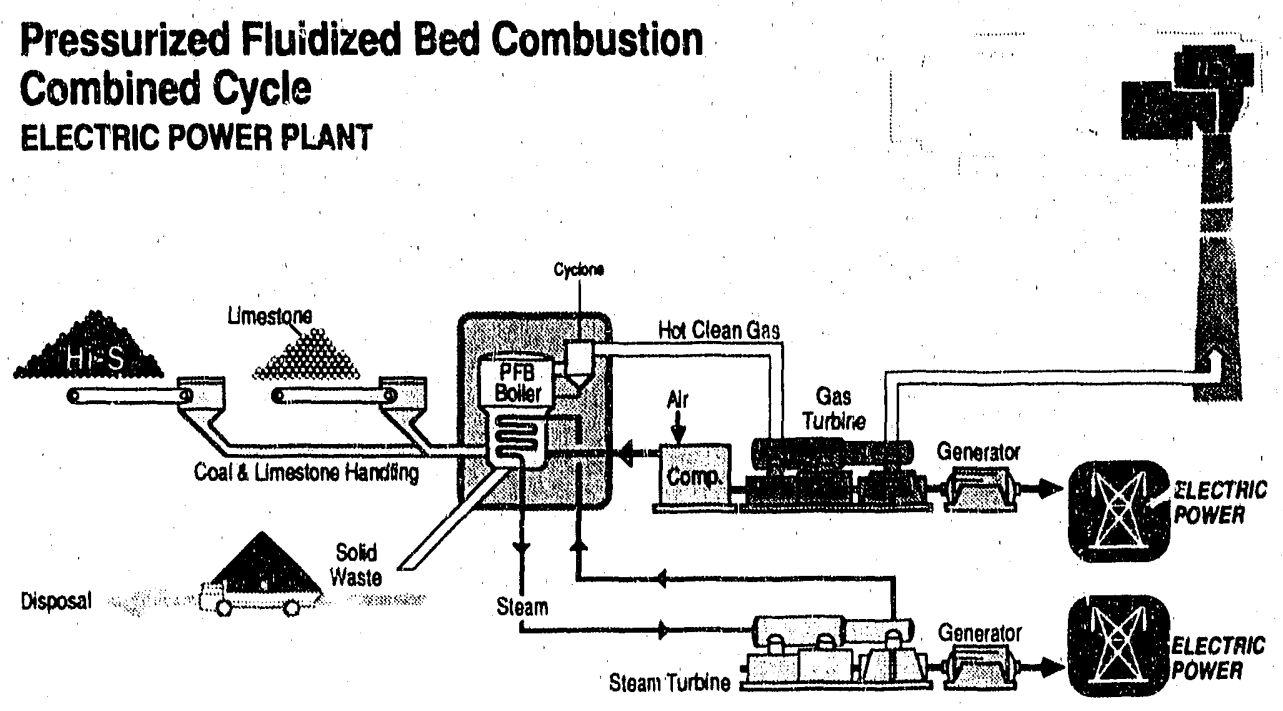

\begin{tabular}{|c|c|c|c|c|c|c|}
\hline \multicolumn{7}{|c|}{ COMPARED WITH CONVENTONAL TECHMOLOGY } \\
\hline $\mathrm{SO}_{2}$ & $\begin{array}{l}\text { NOX } \\
\text { RED }\end{array}$ & mun Baticiancr & power ounvi? & MUNT LFE: & 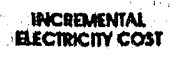 & $\begin{array}{l}\text { captri } \\
\text { cost }\end{array}$ \\
\hline$-95 \%$ & Moderate & $\begin{array}{c}\text { Slight } \\
\text { Increase }\end{array}$ & $\begin{array}{c}40-50 \% \\
\text { MCAEASE }\end{array}$ & $\begin{array}{c}\text { Moderate } \\
\text { Extension }\end{array}$ & 4-6 & $\$ 800-1,000$ \\
\hline
\end{tabular}

\section{Pressurized Fluidized Bed Combustion}

\section{How Does it Work?}

Pressurized fluidized bed combustion (PFBC) utilizes a furnace in which a bed of coal and limestone (sorbent) is suspended in a stream of upward flowing pressurized air. The suspended particles behave like a fluid. During combustion, tubes with flowing water that are located within the bed are heated to form steam. The steam generated is then sent to a steam turbine tor the generation of electricity. Increased system efficiency is realized by combined cycle operation through the incorporation of a gas turbine to recover additional energy from the pressurized products of combustion. A distinctive aspect of fluidized bed combustion is that when coal and a sorbent are injected into the bed, $\mathrm{SO}_{2}$ reacts with the sorbent to produce a dry and benign solid.

\section{What Are Its Attributes?}

- There are no special coal handling requirements other than the addition of limesione to the coal teed.

- Gases require hot particulate cleanup betore entering the gas turbine. No flue gas cleanup is required.

- The fluid-like motion of the solids in the combustion chamber promotes turbulent mixing that improves combustion efticiency and the in situ capture of sulfur dioxide, eliminating the need for add-on removal units.

- The superior mixing also permits combustion at substantially lower and more evenly distributed temperatures. This results in the reduced formation of nitrogen oxides.

- Elevated pressures permit higher combustion intensity and reduce the size of the unit.

- Combined cycle plants, in addition to increasing the efficiency of energy production, can be composed of standardized modules. This leads to ease of installation and a relatively lower cost without the usual economy of scale penalties.

- Modularity provides for staged construction which permits smaller increments of capacity, thereby shortening construction time and lowering financing requirements.

- The space required for PFBC expansion is of the same order of magnitude as would be required for a flue gas scrubber.

- Combustion occurs at temperatures below the ash melting point so that solids accumulation and boller tube erosion and corrosion are minimized.

- Since it is relatively non-sensitive to feedstock, all types of coals or coal wastes can be used.

- The waste generated is a dry, benign solid that can be disposed of easily or usefully employed (e.g., as material for road or building construction).

\section{What Repowering Potential Does PFBC have For Targeted Plants?}

Since type or size of boiler can be repowered by PFBC technology using the existing plant area, coal and waste handling equipment. and stoam turbine equipment, the life of the targeted plant can be extended. Although the initial cost may be

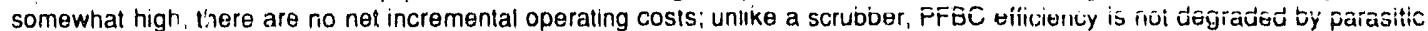
losses. Also, the addition of the gas turbine provides an increase in plant capacity of about 40 percent. 


\section{Atmospheric Fluidized Bed Boiler ELECTRIC POWER PLANT}

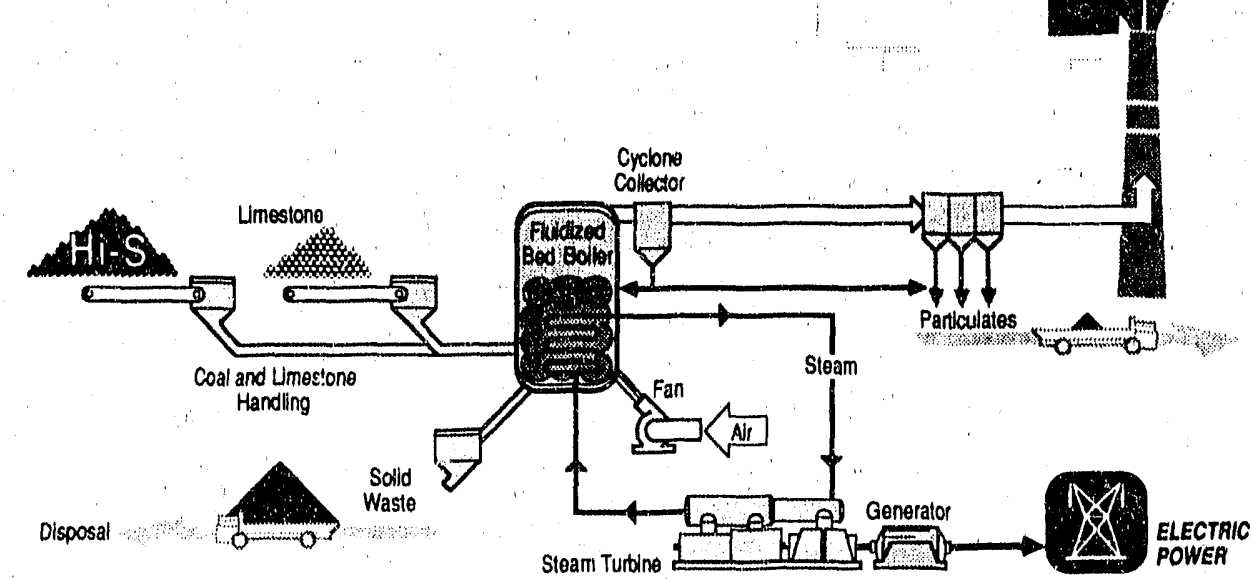

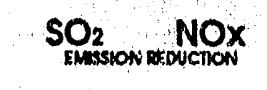

85-90\% Moderate
COMPARED WITH CONVENMONAL TECHNOLOGY"

\begin{tabular}{|c|c|c|c|c|}
\hline PLANT EFFICIENCY & POWER OUTPUY & MANT UFE & $\begin{array}{l}\text { INCREMMAMTA } \\
\text { ELECTNCITY COS }\end{array}$ & $\begin{array}{l}\text { CAPTIAL } \\
\text { COST }\end{array}$ \\
\hline $\begin{array}{c}\text { No } \\
\text { Change }\end{array}$ & $\begin{array}{l}10.15 \% \\
\text { INCREASE }\end{array}$ & $\begin{array}{l}\text { Moderate } \\
\text { Extension }\end{array}$ & $\underset{6-8}{\text { MLL:КพH }}$ & $\$ 70 \underset{\text { PER KYY }}{\$ 700}$ \\
\hline
\end{tabular}

- CONVENMONAL COAL.FIRED ELLCTRIC POWER PLANT

\section{Atmospheric Fluidized Bed Combustion}

\section{How Does it Work?}

A fluidized bed combustor is a furnace in which a bed of solld particles is suspended in a stream of up-flowing air. The suspended particles behave like a fluid. During combustion; tubes with flowing water that are located within the bed and/or above the bed in the flue gas path are heated to form steam. The steam generated is then sent to a steam turbine for the generation of electricity. The distinctive aspect of a fluidized bed combustor is that when coal and a sorbent-..such as limestone--are injected into the bed, sulfur dioxide is absorbed by the sorbent to produce a dry and benign solid. Atmospheric Fluidized Bed Combustion (AFBC) operates at or near atmospheric pressure.

\section{What Are lts Attributes?}

- There are no special coal handling requirements other than the addition of limestone to the coal feed.

- The flue gases require only particulate removal.

- The fluid-like motion of the solids in the combustion chamber promotes turbulent mixing that improves combustion efficiency and the capture of sulfur dioxide.

- The superior mixing also permits combustion at substantlally lower and more evenly distributed temperatures, thus reducing formation of nitrogen oxides.

- Combustion occurs at temperatures below the ash melting point so that solids accumulation and boller fube erosion and corrosion are minimized.

- Since it is relatively non-sensitive to feedstock, all types of coals or coal wastes can be used.

- The waste generated is a dry, benign solid that can be disposed of easily or usetully employed (e.g., as material for road or building construction).

\section{What Repowering Potential Does AFBC Have For Targeted Plants?}

An example of AFBC utility repowering is the Northern States Power project at its Black Dog Station. The existing $85 \mathrm{MW}$ pulyerized coal boiler was upgraded to $125 \mathrm{MW}$ with a bubbling bed design AFBC bolier. It began operation in the fall of 1986. This project has resulted in a considerable reduction of $\mathrm{SO}_{2}$ and $\mathrm{NO}_{x}$ emissions and has realized an extremely tavorable ecoriomic advantage.

Since any type or size of boiler can be repowered by AFBC using the existing plant area, coal and waste handling equipment, and steam turbine equipment, the life of the plant can be extended. Although the initial cost may be high, there are no net incremental operating cosis; IInlike a scrubber, AFBC efficiency is not degraded by parasitic losses. In many cases (e.g., where the capacity of the boiler has been reduced because of aging, or the turbine generator has greater capacity than the boiler, or both), AFBC can be used to repower an existing boller and, in addition to controlling $\mathrm{SO}_{2}$ and $\mathrm{NO}_{x}$ emissions, can increase the boller's capacity. The cosi of conirvis is signififictiiily reduced bacauso ot the value of the increased ranaclity. 
APPENDIX C

MAJOR U.S. COMPANIES DOING BUSINESS IN THAILAND

\author{
Ahrens Grimm-Carrier \\ American International Assurance \\ AT\&T \\ AT\&T Micro Electronies \\ Bank of America \\ Burns \& Roe \\ Colgate-Palmolive \\ DuPont \\ Exxon \\ Firestone \\ General Telephone Directory \\ Company \\ Goodyear \\ Hilton \\ HMC Polymers Company
}

Hughes Aircraft Service

IBM

Kodak

Mobil

National Semiconductor

Northwest Airlines

Phelps Dodge

Texas Pacific

$3 \mathrm{M}$

Transpo International

Union Carbide

United Airlines

Varel Manufacturing

-- plus most Fortune 500 Companies 


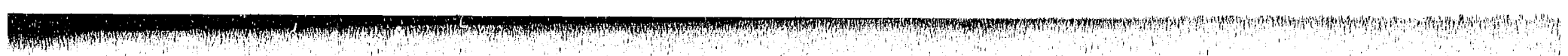
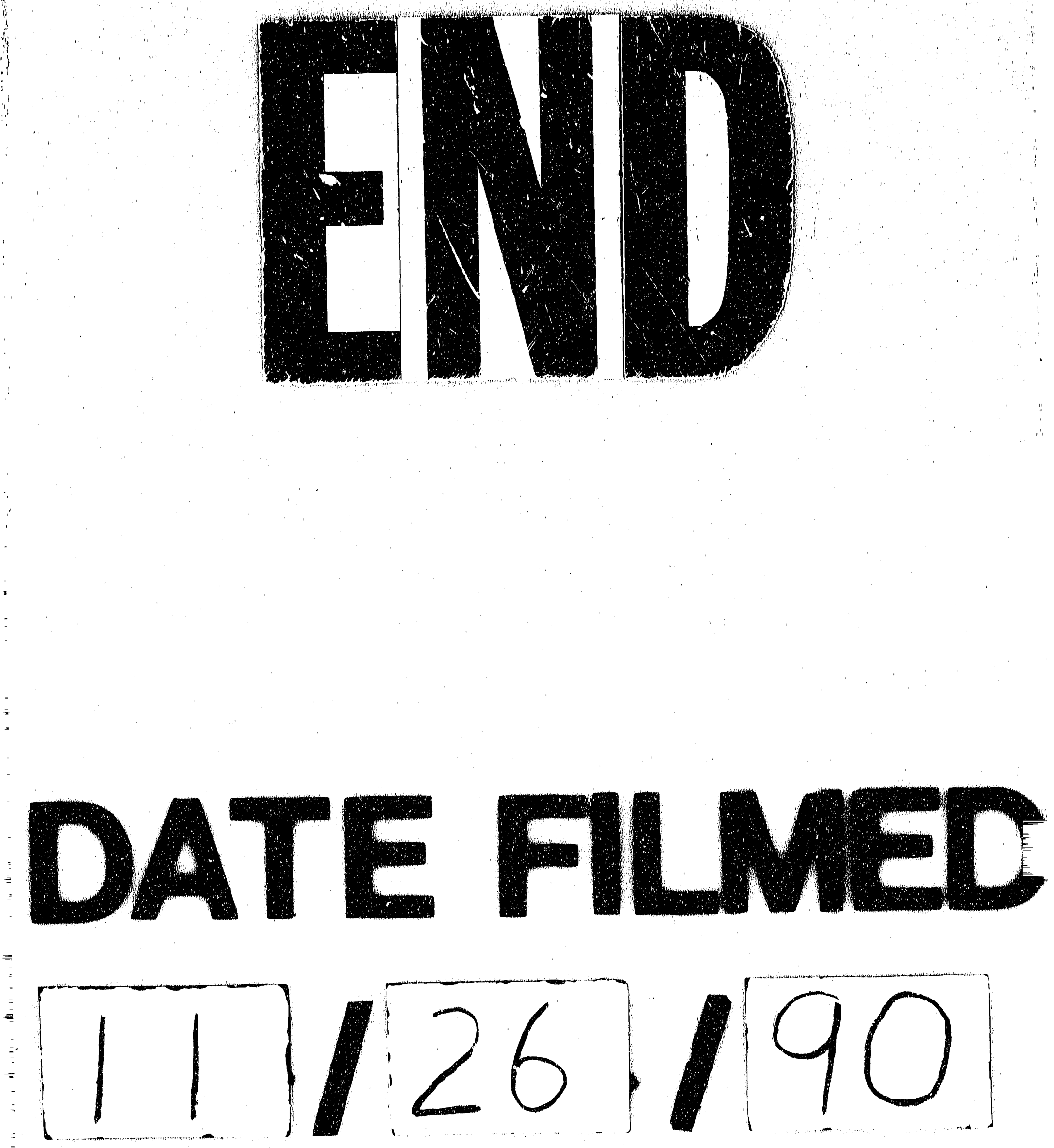
$\because$

$\therefore$ 